\title{
TechnologyEducation in Prospect: Perceptions, Change, and the Survival of the Profession
}

While this Special Section foc uses on issuesrelated to one of the professional fields served by Epsilon PiTau, there ismuch of value to students and practitioners in the otherfields of technology, particularly as werealize ourconnectiveness. Whatever goeswellorpoorly with anyone of ourprofessionalfamily und oubtedly affects the others in the clan. This Special Edition is based on a November 12, 1998, presentation to the 85th Mississippi ValleyTechnologyEducation Conference (MVTTEC) in Rosemont, Illinois. The details of the conceptand its implementation are best told from extracts of presenter Karnes' introductory remarks at the conference.JS

Thirty-five respondents submitted statements for inclusion in this paper after listening to the mournful pleas for assistanceembeddedintelephonemessagesandintheletteraddressedtoeach of them. Toreveal the contextand the climate within which these contributorswere "invited" topreparetheirstatements, the following paragraphs from thatletterhavebeenmadeapartofthis report:

lamabsolutelythrilledthatyouhaveagreed to submit a brief statement for inclusion in a papertobepresented fortheprimarypurpose of stimulating discussion at the $85^{\text {th }}$ Mississippi ValleyTechnologyTeacherEducation Conference at Rosemont, Illinois, on November 12 and 13,1998 . I would not wish to disrupt your demanding schedule, but Ihopeyou canlet mehaveyourcontribution by October 15. To getyoustartedrightaway, here isthemessage thatisgoing toeach person who has agreed to help with the paper. (Of course your name topped the enclosed listof distinguished contributors until the Microsoft Word alphabetize buttonwasstrokedinadvertently!)

Enclosed are copies of:Tom Erekson'sletter of March 13, the MVTTEC program to which herefers, and Jerry Streichler'sletter of September 14 in which heexpresses an interest in having a copy of the proposed paper presentedforreview.

You will note that Tom [MVTTEC chair Thomas Erekson'sinvitation to him to present] seemed toleavethedoorwideopenwhenhe putmynameonthe programbutdidnotpose questions as he did for the other two presentations scheduled for the morning of November 12. Heconcurred, however, with my suggestion that the following is an appropriate and compelling question to be addressed as we approach the year 2000: What are the most critical changes or improvements which must be made if technology education is to be an integral component of strategic importance in the total educational enterprise of the new century?

While the many experiences enjoyed during my 26 years of retirement from the University of Illinois have been rich and rewarding, thatlength of time away from the fraymakesitpresumptuous of me to attempt aresponse tothe preceding question without agreatdeal of assistance. Iam therefore, with Tom's approval, taking advantage of this delightful opportunity to call in chips from former students and colleagues! I have the unmitigated gall to suggest thateach of you recallyour joyous days of graduate study as you respond within the range of 450 to 550 carefully chosen words to the preceding question under the assumption that your answer is to account for a critical share of the totalscore on yourcomprehensive doctoral examination!

During the 1998 ITEA conference in Fort Worth I sensed a disturbing degree of the anxiety, desperation and defensive posture with which many professionals in our field reacted during the late 1950's to the rather sudden and drastic curtailment of industrial and otherpractical arts and elective subjects in favor of increased emphasis on science, mathematicsandforeignlanguagesasahasty, knee-jerk response to Sputnik. The signals sensed in Fort Worth promptme toenclosea copy of one of my papers written in the threatening environment of the post-Sputnik erawithin whichmyelectiontothepresidency of AIAAoccurred. The enclosed copy of John Gallagher's 1993 paper in response to my 1960 piece should be of particularinterestas youprepareyourstatement.

All but a few of the contributors responded promptly. The gentle and genteelpowers ofpersuasionemployed on the tardyranged fromabsurdforms of flattery to threats of violence. One was told that withouthis scholarlyinput the $85^{\text {th }}$ Conferencewould have to be cancelled. The few who attempted to bolster their plea for additional time with thatoldand badlyfrayed bitabout being under attack from the rear by infamous predators of southernwaters werereminded thatdraining theswamp is the prerequisite to victory in alligator combat! The last two contributions arrived only a few minutes before the

\author{
M. Ray Karnes
}

with

Thomas R. Baldwin

ElazerJ. Barnette

M.James Benson

David C. Bjorkquist

Sharon A. Brusic

JamesJ. Buffer

RodneyL. Custer

Paul W. DeVore

William E. Dugger

MichaelJ. Dyrenfurth

Thomas L. Erekson

Rupert N. Evans

Dennis Herschbach

Daniel L. Householder

Everett N. Israel

ScottD.Johnson

Theodore Lewis

Donald G. Lux

G. Eugene Martin

Jerome Moss, Jr.

Stephen Petrina

David J. Pucel

Willis E. Ray

Mark E. Sanders

Ernest N. Savage

Michael L. Scott

Kendall L. Starkweather

SamStern

Leonard F. Sterry

JerryStreichler

Richard A. Swanson

Tim L. Wentling

Brenda L. Wey

R. Thomas Wright

Karen F. Zuga
Dr. Karnes is Professor Emeritus at the University of Illinois and Professor Emeritus atThe University of Southern Mississippi. He is a member-at-large of Epsilon PiTau and holds the honorary's Distinguished Service Citation. 
"Send Now" button would have transmittedmessagescontainingsubtlereferences to theirrespective ancestors. Myhope is that the fewrespondents whomaderatherextensive use of flatteryin theirpaperswill notbeoffended upon learning that nearly all of their glowingremarkswere deleted before any attemptwas made to evaluate theircontributions andrecord grades. I have asserted prerogative to offer remarks, which follow the thoughts of the 35 graciousrespondents.

ThomasR Baldwin, Dean CollegeofTechnology Pittsburg State University

The Challenging Road to Oblivion

The firstissuethatmustbeaddressed is perception. What are we, whatare we about, and why is studying technologyimportant? Technology and technologyeducationareconceptsthat needaclear, generallyunderstoodand acceptedmeaning. Wehaveundertaken this effort, but its completion is on a distanthorizon. Peoplestill puzzle overthequestion, Whatistechnology, who are technologists, and what do theydo? There is a lack of understanding among engineer, technician, scientist, and the fields they work in. What is therelationshipamong the bio technologist, chemical technologist, medicaltechnologist, engineeringtechnologist,mediatechnologist, mechanicaltechnologist, and the manyothers thatshare the conceptof technology and its applications? When we have people educated to the point of explaining the significance of theserelationships, they will be able to understand theneedfortechnologyeducation.

The secondissue is attraction. If we cannotattractsignificant numbers of brightyoungstudents into the field of technologyeducation and thenkeep them in education, we will cease to exist and this will no longer be an issue. The value we place oneducation is evident by the salaries we proposetoattractthebrightestandbestto work with our children. Until beginning teachers' annual incomemoves them from the povertylevel to a point significantly above that of their fellow graduates, we will continue to slide toward oblivion. This will leave the door openforinadequatelypreparedpeople to fill the void or for school personnel and thepublictoassumethatagenerous supply of computers in the school will meetfully theneedfortechnologyeducation. The shortage of qualified people for our university programs is a major deterrent to progress in our field. We needtoencouragemorequalityteachers togobacktoschoolandpreparetobethe university instructors for tomorrow.

The lack of anaccepted andrepresentative curriculum of high quality is another compelling problem. The completion of the Technology for All Americans Project and resulting curriculum will hopefully nullify this as an issue, but the manyindustrial arts courses withnamechanged totechnologyeducationleavemecautious withreference to prospects for the future. Tight local control of the school in many states will probablycontinuetostandin theway of the curriculardevelopmentsinresponse totechnologicaladvancements.

\section{EazerJ . Bamett Interim Dean SchoolofTechnology \\ North Carolina Agricultural \& TechnicalState University}

\section{Critic al C hangesin Tec hnology Education}

The new millennium will usher in many changes and challenges for the educationalenterprise thatwilleducate theyouth of thisnation. Many of thenew millennium educational activities will becenteredontheneedforenhanced computerskills, development of toolsto assess thelevel oflearning, and committed to improving the quality of the studentperformance.Severallearnedsocieties are addressing these educational activities and developing standards for preparing students in their respective disciplines for the 21st century. For example,standardshavebeendeveloped forscience and math. For the discipline oftechnologyeducation, thestandards projectTechnology for All Americans is nearing completion.

It is critical for the survival of technol- ogyeducation thatleaders of the discipline understand the reality of what is happeningin thetotaleducationalenterprise.Technologyeducation teachers and administrators should spend less time debating issuessuch as technologyeducation versus trade andindustrialeducation, technologyeducationversuseducationaltechnology, and otherissues thathave been around for many years. More time and energy should be directed toward broader issues related to the total educational enterprise.Thesuccessandacceptance oftechnologyeducationas a discipline integral to the total educational enterprisedependsonhowwe (themembers andleadersoftechnologyeducation)interactwithothersoutside ourdiscipline.

Themembershipoftechnologyeducation can begin this interaction by asking to what extent is technology education positioning itself to beintegral to the U.S. Department of Education's Strategic Plan 1998-2002 as set forth by Secretary Riley of the DepartmentofEducation.Thisstrategic plan is framed by seven educational initiatives. The first three are a direct response to PresidentClinton's Call-toAction for American Education in the 21 st Century, and the lastfourare strategies for implementing the first three initiatives.

These seveneducational initiatives will define the educational enterprise forthenew century. If technologyeducationistobeanintegral component of strategicimportanceinthetotaleducationalenterprise of the new century, it is critical that leadership of technology education include in its strategic plan elements of the seveneducationalinitiatives and thus help ensure that all children will be able to: (a) read independentlybytheend of thethirdgrade; (b) masterchallengingmathematics, including the foundations ofalgebraand geometry, by the end of the eighth grade; (c) be prepared forand able to afford at least two years of college by age 18 and be able to pursue lifelong learning as adults; (d) have a talented, dedicated, andwell-preparedteacher in their classroom; (e) have their classroomconnected to the Internetby the year 2000 and be technologically literate; (f) learn in strong, safe, and drugfreeschools; and (g) learnaccording to 
challenging and clear standards of achievementandaccountability.

The following statements and questions fortechnologyeducators to ponderevolved out of thelastfoureducational initiatives. All students should:

- Have a talented, dedicated wellprepared teacherinevery classroom. Secretary Riley (1997) stated in his back-to-schoolspeechthat 2.2million teachers will need to be recruited in thenextdecade, andheissuedspecific challenges to higher education, communities, states, local districts, and Congress. Will technologyeducation be proactive or passive and thereby continuetoseetechnologyeducation classrooms with teachers who are not certified to teach technology education?

- Have their classrooms connected to the Internet by the year 2000 and be technologically literate. Technology Innovation grants totaling $\$ 30$ million are available to help support the challenge of preparing newteachers and supporting existing ones to teach effectively. It is clear that the Secretary focuses ontechnology and the use of computers; but he stresses the importance ofenhancing teacherskills and their professional development, especiallyin the use of computers and advancedlearningtechnologiesintheir classrooms. Technology education must obtain the funding required to educate students who will be technologicallyliterate. To accomplish this critical change, there must be more involvement of secondary school technology teachers, local and state technologyeducationsupervisors, and technology education teacher educators at the nationallevel where funding decisions are made.

- Learn in response to challenging and clearstandards of achievementand account-ability.Secretary Rileystresses the importance of voluntary national tests that show what students have learned and what they have not learned. Is the Technology for All American Projectbeing shared and discussed with key leaders in the Department of Education who can promote the cause of standards for technology education across disciplines?

- Learn in strong, safe, and drug-free schools. This fall there will be three regional conferences on Improving America's Schools. Theseconferences will be held in the following cities: Portland, OR; Denver, CO; and Nashville, TN. Will the leadership of the discipline oftechnologyeducation attend one of these conferences to network with leaders from the total educationalenterprise?
Ihavebeeninvolvedintechnology educationfor 25 yearsasteacher, state consultantfortechnologyeducation, teachereducatorfortechnologyeducation, departmentchair, and nowinterim dean of aschool of technology. From all of these positions, I have seen the discipline progress rapidly. I have also seen the discipline becomestale and at timesstall. Technologyeducation must be dynamic and thus preparedforchange. Weshouldnotforget ourhistory. Therein lies the foundation for the future of the discipline. We must understandhowtechnologyisimpacting the discipline from many angles. Wemustdetermine the course of technologyeducationatalleducationallevels and how it relates to other disciplines. If the profession is to be an integralcomponentofstrategicimportance in the total educational enterprise in the 21 st century, the discipline mustanticipateandrespondrapidly to accelerating technological and sociologicalchanges.

\section{References}

Clinton, W. J. (1997). President Clinton's call to action for Americaneducation in the 21 st century. [Online document.] U.S. Department of Education. http:// unw.ed.gov

Riley, R. W., \& Smith, M.S. (1997). Strategic plan, 1998-2002. Online document. U.S. Department of Education. http:// wnw.ed.gov

\section{M.J amesBensen, President BemidjiState University}

\section{Invent the Future Rather Than Reinventthe Past}

Iftechnologyeducationis to be an integralcomponentofstrategicimportance in the total educational enterprise of the new century, it mustembracechangeatarateneverevenconceived ofin the past! Changemustbe central to the way that people think, act, and assess. Technology, byits nature, is the engine of change. Itisessential that the verycore of the technology education curriculumleads and encouragesstudentstobechangeagents. Harry Quadracci, CEO of Quadgraphics, oncestated, "Changeis ourbread and butter, doing itbetter thanevery- one else is our job security!" Mr. Quadracciunderstands verywell that the lifeblood of his enterprise is the abilitytomoveatlightningspeedand to deliver quality service to satisfied customers. Imagine a technologyeducation program that is devoted to excellence, willing to never teach the same contenttwice, andenablesstudentsto grow to levels of excellence in performance thatdazzletherestof theschool and community!

The amount of know-how, orcontent, in thestudy oftechnologydoubles about every 18 months. To keep our studentsengagedinrelevantlearning experiences dictates that we teach throughthe designapproach, useexperiential, first-hand involvement in solving problems, and engage themininventing thefuture.PricePritchettstated that "the bestway to predict the future is to invent it." This suggests that the bestway to know what's coming is to putyourself in charge of creating the situationyouwant.Bepurposeful.Look atwhat's needednow and setabout doing it. Action works like a powerful drugtorelieve feelings offear, helplessness, anger, uncertainty, or depression. Mobilize yourself because you will be the primary architect of your future. One of the keys to being successful in youreffortsis to anticipate. Accept the past, focus on the future, and anticipate. Considerwhat's coming, what needstohappen, and howyou cannise to the occasion. Stay loose. Remain flexible. "Instead of changing with the times, make a habit of changing justa littleahead of the times" (Pritchett, 1998, p.40). Soitmustbeinleading technologyeducationintothenewmillennium.

\section{References}

Pritchett, P., \& Pound, R. (1998). The Employee handbookfororganizational change. Dallas, TX:Pritchettand Associates.

David Bjorkquist, ProfessorEmeritus University of Minnesota

\section{Leamer-Centered Education in Technology}

It ismyintentiontosuggestchanges andimprovementsforeducationintechnologyinclusive of technologyeducation, vocational-industrial education, 
humanresourcedevelopmentinindustry, and industrial technology. These are the severalareas thatgenerallyencompass the responsibilities of members of the Mississippi Valley TechnologyTeacherEducationConference.

Many of the goals of public educationfocuson developmentforadultlife including preparation for one of the universal activities of adults; world wide, that is work. Work, both paid and unpaid, occursinplaces of employment, homes, and throughout communities. Much of the school's curriculum is designedtoprepareyoungpeopleforwork, and justification for subject matter is often economic. School curricula are keenly attuned to the suggestions of businessandemployers.

When long-term, mutual commitmentswere made by employers and employees, business needs were perceived to serve individuals as well. Today, lifetime employment is unlikely. Worker needs differ from those of employers. Manywhoareenteringtoday's labor force will be temporary or contractworkers, and many more will experiencelayoffsandunemploymentas part of their careers. Employerswill not guidethecareeradvancementofworkers and will notberesponsible forinsurance plans, pensions, vacations, and sickleave.

With employers playing a reduced role in the lives of workers, the locus of planning can be shifted from the workplace.Formany, thehomecanbecome the center of attention. Holistic planning (considering the family'sresource base, lifestyle, and what it wants to produce) can include the work of the home, community, andemployment. As disembodied employees hired becauseoftalentsappropriatetocomplete an employer-defined task, individuals cannotafford toplanaround theneeds of aparticularemployerorestablished occupation. Within the context of this psychologyandeconomics, individuals should know and develop those skills that are most satisfying and are performedbest.

Importantlearning can occurin all forms ofinstruction in machine-based, political-social, and othertechnology. Knowledgeoftechnologyusedtoorganize work and define jobs, to control processes and persons, and to return power to individuals are examples of critical social-political technologies. The discovery, exploration, and development of talents can be realistic in classeswheretool-andmachine-based technologyis taught. Manylessons of technology will be economicallyimportant and others will enhance the satisfaction of daily living.

Control of a learner-centered curriculumintechnologycannotbegiven over to those with self-centeredinterests. Business leaders and employers, to whom a continuing supply of able, cost-effective workers is important, shouldbeheardbutshouldnotdictate. Vendorswhosellenticingpackages of instructionalmaterials and equipment aremorelikely tobemotivatedbysales prospectsthanbythelearning needs of studentswhouse theirproducts. Aroutine course of instruction created by outside powersruns counter to the decision-making and controlling skills that learnersneed.

If instruction in technology is to be strategically important, it must be of worth toits clients. Atpresent, the conditions and impact of work make that an important focus for all citizens. It is of comfort to know that employers, families, and communities will bewell served by a learner-centeredstudy of technologythatproducesindependent, self-assured, problem-solving citizens.

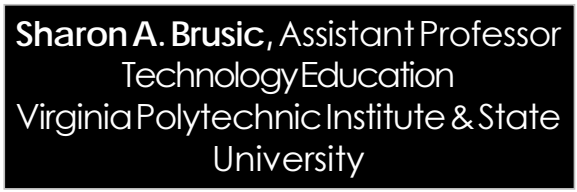

\section{Commitmenttoa Cure}

Mosttechnologyeducatorswould agreethattechnologyeducationisgeneraleducationand thatgeneraleducationisintended to meet theneeds of all students in the school. But, any keen observercan clearly see that the vast majority of technologyeducationstudentsandteachersrepresentonlyabout halfof the population. Technologyeducationis clearlynotmeeting the needs of everyone when the overwhelming majority of its students, teachers, administrators, andleadersis dominated byonegender:males. Canaprogram trulyberecognized as generaleducationifitchieflyattractsmalesandseeminglycaters totheneeds ofonlyonehalf of thepopulation?

Despite some attempts in the past decadetobroadentheappeal of technologyeducation to both males and females, there is still an incredible gap infemalerepresentationintechnology education at all levels. Why is this the case? Isitbecause girls and womenare notinterested in technology? Are femalesless capableintechnologyand thereforelessapt to participateintechnologyeducation? Does technology education need to change or do females need to adapt? How can we explain andrectify this representation gapintechnologyeducation?

Technology educators are remiss if they continue to overlook the seriousness of this incessant problem in technologyeducation. Justas alcoholism, dysentery, heartdisease, and tuberculosis require appropriate and aggressivemedical attention, this chronic genderrepresentation problemin technologyeducationrequiresappropriateand aggressiveremedial therapyinorderto correct the situation. A multifaceted approach thatinvolvescritical analyses of K-12curricula, teaching strategies, facilities, and public relations efforts will likely lead to finding a cure for this chronic problem. But, itwon'thappen unless dedicatedresearchersandeducatorsmakeacommitmenttofindinga cure by soliciting assistance and guidance from experts. This problem is not likely to be solved from within by technologyeducatorsalone. Itwillundoubtedlyrequire external evaluations, courageouschanges, and boldattemptsto alteringrainedpatterns ofbehaviorand entrenched practices in technology educationprogramsandorganizations.

As educators critically assess therole of technologyeducation in the total educational enterprise, this persistent problem demandsforthrightattention and positive action. Technologyeducation will never truly be general education - an integral and meaningful componentofeverystudent'seducational experience —unless this obvious flaw is remedied through whatever meansisnecessary to doso.Insodoing, it isjust possible that technologyeducationmay finallyberecognized as an educational program that serves the needs of allstudentsin the nextcentury and beyond. Moreover, this focused approachmayalsobethemuchsought 
after antidote to ailments such as decliningenrollments, teachershortages, andprogram closures that threatenthe future oftechnologyeducation.

\section{J ames] . Bufier,J r., Professor and Associate DeanEmeritus \\ The Ohio State University, and \\ Horace G. Fralin Professor andDean Emeritus \\ Virginia Polyłechnic Institute \& State University}

Foryears, I've been plagued with a recuming dreamthatlwasscheduledto submit a written report to one of my former (not old) professors, and not knowing how I would find the time to fulfill the commitment. Now, after arriving home after traveling for several weeks and needing to catch up with personal and professional commitments, I find myself with a similar dilemma.Time constraints withstanding, I am humbled by RayKarnes' request that I participate in his professional rodeoandsubmitacontributionforthe MVTTEC. Besides, this may be the way to bring closure to my recurring dream. The good Lord knows that one should not tempt the wrath of M. RayKarnes.

Addressing the assigned topic is, in itself, a major challenge but also an opportunity to provoke thought and dialogue among thoseresponsible for influencing educational policies and programs thatwill helpensure technological literacy in our society. Thirtynine years ago, Karnes (1959) demonstrated his vision for the improvement of technologyeducation in his classic work, "Improve orPerish." A number of very capable professionals, many with whom I had the privilege of working with, were influenced by Karnes' recommendationsas evidencedbythe direction of their professional initiatives andaccomplishments. Sowhyarewe revisiting?

Issues and Concerns. Onemightrespond thatweareinterestedincontinuousimprovementsince, as educators, commitment to achieving qualityand excellence in our endeavors is a high priority. Given thestatus of the technologyeducation profession today, such actionseemsprudent. Arealitycheck suggestsmajorifnotalaming decreases in K-12 enrollments; closing and curtailmentofteachereducationprograms; shortagesofqualifiedteachers; andlack ofunderstandingamongpracticingeducators (K-12and collegiate), laypeople (parents,students, andcommunityleaders), andpolicydecisionmakers (elected andappointedgovernmentofficials) of its mission and goals. Too often, the typicalresponse fromthegeneralpopulousis that technologyeducation is the study of computers. Wow, this is like suggesting that30years ago industrial arts was the study of wood-or metalworking machines. Bottom line is that the sum of these factors equals lessthan-desirablesupportfortechnology education by ourcustomers.

Can we assume that the majorresearchand developmentefforts of the past30years, manyfunded by federal andstateagencies, thatfocusedoncurriculum development, learning and humanbehavior, teacherpreparation, leadership, and technologyalong with a few thousand papers presented at local, state, and national conferences weremisdirectedorunheeded? Or,were thereotherreasonsfortheapparentdeclineintechnologyeducationprograms thatweshould considerwhenseeking waystoensure thattechnologyeducationistobeanintegralpartof theeducationalenterprisein thenextcentury?

From myperspective, too manyindustrial arts educators were following theirownagendawithoutconcernfor the opinions of the total professional community. Some went forward and programsbecame disparateunitswithoutany unifying theme. The endresult is that technology teachereducation enrollments declined, "leaders" have embracedquasi-engineeringprograms at the collegiatelevel, and enrollments andsupportfork-12programsdeclined. And to fill this void, our colleagues in mathematics,science, andinstructional technology (the area mostlay people andeducatorsseemtoequatewithtechnologyeducation) are now providing theleadershipfortechnologyeducation.

Recommended Changesand Improvements. Manypopularbooks on the best sellers' list, which focus on reengineeringandleadershippracticesto improveindividual performance and corporate outcomes, mightbe ofsome benefit in addressing this challenge. But, ratherthanscan the menus of the day for a quick orpopularfix, allowme torecommendsomebasicleadership andmanagementprinciplesthatmight be effectivein helping to achieve our desiredgoal.

1. Focus on what are perceived as the unique mission and goals of technologyeducationanddevelopconsensus among the profession to limiteducational initiatives under the sponsorshipoftechnologyeducation.Consensus of what this unique mission is or should beappears to have eluded the profession; and as a result, there appearstobeaconflictbetweenwhat the leadership sees as being the mission of technologyeducation and the mission as perceived by the field's customers. These differencessuggest that the customers are not satisfied with the productcreatedbytheleadershipandhave chosen to direct theirloyalty and funds elsewhere.Myhopeisthat theongoing Technology for All Americans Project will provide the compass to redirect andenergizefuturetechnologyeducation initiatives.

2. When formulating the mission statement,rememberthehistoricalroots andfoundationfrom whichtechnology education has evolvedandrecognize theenduring valuesstudents derivefrom its diverse instructional programs. Consider policies and goals that are supportedbyhistorical precedencebutare alsoeducationallyand technologically relevant to the 21 st century. While the materials, tools, equipment, and processes thathave been part of our programsareeverchanging, thebasictechnological principles and conceptsremainconstant, thus providing continuity and integrity to the discipline.

When considering this second principle, build upon the strengths of the profession and its many accomplishments. Wehavealottobeproudofand need to capitalize on these positive aspects. This includes technology education's rich historical record of laboratory-based curriculum and instructional programs; quality professional and scholarly publications; outstanding professionalassociations and affiliations with government, business, and otherprofessional organizations; andits unique contributions to education andsociety.

3. When developing curriculum guidelines fork-12 and collegiate programs, focus again on technology education's centralmission. Decide 
whether technologyeducation is a method of teaching and used to enhancetheteaching, understanding, and application of other established disciplines such as mathematics and science. Or, isit a discipline or subject that focuses on thestudy of technology?

Hopefully, the latter statement will bechosen and the profession will then determine how technology may be modified to limit the parameters of its curriculum. My analysis of the articles appearing in the profession's publications and of the presentations and exhibits at its national conferencessuggests that the profession has chosento focus instruction on the study of technology, broadly defined with a plethora of such modifiers as manufacturing, textiles, medical, engineering, adinfinitum. Frankly, this "we're anything youwantustobe" approach willseethe demise of technologyeducation as a discipline with integrity and value that earnitanimportantpositionin theeducational complex of thenextcentury.

The middle of the road approach assumesthattechnologyeducationisa hybrid and is used as a method when appropriate to other educators and policymakers. Itbecomes a discipline orsubjectwhenateacherissuccessful in delivering instruction that provides added value to the curriculum as evidencedbystudentchoice orrecognition by othercolleagues. I would hope thattheformerisnotthe primarychoice of educational leaders since this perception of the field would certainly curtail the expansion and continual evolution oftechnologyeducationasa recognized programarea.

4. Recognize the value and need for technologicalstudiesinoursociety that will enable citizens to understand and copewith themyriad of changesoccurring in our daily lives. Build curriculum andinstructiononthose uniquetechnologicalconceptsandknowledgethataffectoursocial, economic, and political well-being, butwithoutreplicating the domains ofotherdisciplinesorsubjects.

5. And finally, be proud of your professionandmakeacommitmentto workcollectivelyforacommongoalthatofpromoting theadvancementof technologyeducation as a viableand integralcomponentofoureducational fabric. Above all, remain passionate about your profession and do not sell

out to the whims of others riding a bandwagonderivedfrom themenu of whatlooks good today. Hopefully, the collective wisdom of the professionals participating in this scholarly symposium will work to achieve a win-win situation. In reality, the winners will be the future students and citizens who will provide the leadership for the next century.

In summary, my wish is that future technologyeducationprogramswill be framed torepresent the fundamental valuesasespousedin the Seven Cardinal Principles as well as the national goals of America 2000. And, moreimportant, all learners will have opportunities to further their development in activelearning environments (laboratories) that involve doing and the application oftechnologicalknowledgeand skills to achieve desirable goals. Empowermentandindependence (self-reliance andresourcefulness) will be the ultimateoutcomesandcommunitybenefits of this goal.

Theattainmentofthesegoalscannot be adequately achieved primarily throughinstruction limited to computer simulations or toys such as Tinker Toys orLEGGOblocks. Rather, studentsneed to have experiences with real tools, materials, equipment, and processesin laboratorysettings thatenablethemto achieve technicalskillsandcompetencies to solve problems confronted in daily life experiences.

RodneyLCuster, Chairperson Department of IndustrialTechnology Illinois State University

\section{Prospectsforthe Future: It'sOur Call}

Ourchargewastoidentifyneeded changes. However, itwould be a mistakenottoaddress the areas wherewe should persist with current practice beforerecommending changes. I will address theseandthenswitchtoseveral items that will require substantial change.Muchofthegeniusandappeal of technologyeducation-related programs over the years has been our "hands-on" orientation. High percentages ofstudentslearn best when they areactivelyengagedinmeaningfulac- tivity. At all cost, we must resist and rejecta move to simply talk and think about technology (its history, role in society, implicationsforthefuture, etc.). It is also vitally important that the professiondoeverything thatcanbedone tocapitalizeonthesoon-to-be-released standards derived from the Technology for All Americans Project. This should include an array of spin-off activities including curriculum developmentand teacher in-service, as well as assessmentand programstandards. Wemust find ways to make the most of this vitally important effort. A third thrust is to continue to find ways of providing inservice programs for teachers. A numberofteachers, while open, interested, and willing tolearn new content and skills, will not be able to do so without help. Theoldaxiom that "weteach how wewere taught" persists. Ourteachers whowanttochangeandgrowneedto be given the opportunity tolearn from theprofession's best.

NeededChanges. Threemajorproblems mustberesolved if the profession is to become and remain viable. First, we are on the brink of a crisis in technology teachereducation. Shrinking numbers of universities and colleges areofferingtechnologyteachereducation. If this pipeline issue cannot be addressed, the profession will starve fromalack of supply. Asecondchange ismore of an opportunity. Tremendous opportunities exist to partnerwith science, mathematics, andotherteachers to deliver technologyeducation. The evidence of a new openness is clear. Technologyeducationisrepresentedat NSF. The National Research Council's ScienceStandards contain asignificant technologyeducation component. Growing numbers of principals, parents, and policymakers are becoming aware of the value of technologyeducation. If we can find ways to work creatively and collaboratively with teachers from otheracademicareas, ourfuture in the schools could be very bright. We're likely to fail if we attempt toaddyetanotheriteminto thealready crowded curriculum. The keytoinclusionisgenuine collaboration. Competition and exclusion simply will notwork.

Finally, if we are to become a viable forcein theschools, wemustlearnhow tospeakalanguage that therest of the worldunderstands. Mostpeopleunder- 
stand technology, but some of us do not. The Standards should be a major help, butthey will notbeenough. As a profession, wemustfind ways of talking aboutand, probably much more important, showing the public whatwe meanbytechnologyeducation. In order to value our contribution, people must firstunderstand whowe are.

\section{PaulW.DeVore, Professor Emeritus West Virginia University}

\section{ResistancetoChange}

The questionyouraise assumes that technologyeducation should beanintegral component of strategic importanceinthe totaleducationenterprise. You may be able to getaway with this assumptionamongthetechnology-education-true-believercrowdwhilerelaxing at the hotellounge, but not in the realworld. Justbecausethetruebelieverssay technologyeducationis of strategic importance does notmakeitso. We doknow that technologicalinvention and innovation are the keys to economic growth and development. And we know that a technologically literate and creative citizenry is essentialinaglobal competitivemarket. We also know that technological knowledge and know-how are vital ingredientsinanyscheme of national and civil defense.

Institutions, governments, and bureaucraciesdonotchangethemselves. Theyare changed from the outside.So, as much as we might believe we can change the profession from within, the lessons of history are againstus. Nonetheless, since I was asked torespond to the question, l offer the following possibilities to a few courageous leaders abouthowchange canbeattained to meetthechallenge of thenextcentury.

One way is to obtain nationallegislationthatmakestechnologyeducation the "integralcomponent" referred toin the question. I doubt that this is possible, given the currentstate of affairs. There are too many weak sister programs out there. Who would want to supportlegislation thatmerelyperpetuates the present? We might have a chanceifweagreed toinclude, as part of the legislative goal, a program that eliminatesallweakundergraduateand graduateteachereducation programs, public and private. These weak programs only perpetuate the problem. Thereis precedenceforthissuggestion. The medical profession, with heavy outside pressure, made the move to eliminateweakprogramsover 100 years ago. The result of the change was the creation of a medical profession that today provideshealth caresecond to none in the world.

Seeking a political solution through national legislation, however, will only delay the inevitable. The problems the profession facesrequire long-termefforts outside the control of the present structure. The problems faced by the field of technologyeducation are too complexto beleft to the shifting views of peripatetic school administrations and the changingagendasandcommitments of colleges and universities. A betterwayis to create a free andindependent, dedicatednationalacademy orcenter of exceptionally high quality. Linked to the national academyorcenterwould be anumber ofregional centers. These regional centers would replacecurrentantiquated teachereducation programs. Theacademyand the regional centerswould bestaffed by the brightest and best within and outside the profession, none of whom with permanenttenurebutall of them detached fromreactionaryinfluences.

The establishment of the national academy withregional centers would enable the professionto attain the critical mass so necessary in the complex field of technological studies. National and regional centers will provide the profession with greater political clout, prestige, and visibility. And, if linked appropriately with the private sector, the field will be supported more adequately in all ways. Moving in these directionswillmake for a dynamicand prestigiousprofessioncapable ofmeeting the needs of our youth in technologystudiesin the next century.

WillamE Dugger,J r., Director Technology for All Americans Project InternationalTechnologyEducation Association

\section{Technology Education inthe Millennium}

Technologyeducationhasthegreatest hope and vision of any school subject in the next millennium. It can helpevery citizen of the future develop technological literacy thatwill prepare themforanera of certain change and innovation. Having a technologyeducation is as important as being able to readasonnetor determine the square rootofanumberorknowing the effect of soil erosion in Asia.

Aswe move into the year 2000 and beyond, itisimportant that technology educationbecomeanacademicsubject. In doing this, the profession must verify the intellectual domain (knowledge base and process base) that is essentialforeveryonetobetechnologically literate. Also, it is important that we become close relatives with science, mathematics, socialstudies, and humanities in the public schools. As a result of this, we must distance ourselves from the traditional vocational offeringsbecause of themisconception that we are only in public schools to prepare people forjob-entryskills.

In terms of our content, we must identify what every child should know and beabletodoinordertobetechnologically literate. This means that we must divorce ourselves from anindustrial contentbase and moveto atechnological contentbase. Itis also important thatwebecomealigned with offeringsuch topics as introduction to engineering at the late high school level. Engineering concepts may also beincluded in earlier grade levels at the elementaryandmiddleschool.

Itisimperative thattechnologyeducation courses comply with standards relevant to the future. TheStandardsfor TechnologyEducation: Contentforthe StudyofTechnologymustbeusedasa meansfordeveloping curiculaingrades K-12. Also, as a result of Phase III funding, hopefully our profession will embracestandardsforstudentassessment, teacherenhancement, and teacher preparation, and meet fully the new programstandards. Itisimportant that the profession rally around thesestandardsasameansforpropellingtechnologyeducationintothenextmillennium.

Finally, we must developaresearch agendaforthestudy oftechnology. This research agendashould be actively pursuedinthefuturesothatweareable toprovide quantitative and qualitative answers to questions pertaining to the effects ofteaching andlearningintech- 
nology education. In addition to strengthening researchinuniversities as we plan for the future, it is vital that classroomteachersbeprepared topromote and pursue classroom-basedresearchona day-by-daybasis.

All of the above items are mostimportant in moving us from an elective areain the publicschools to arequired subjectand an integral part of the core education of allstudents. Onlythrough much work and change can we be viewedin the future as anessential part ofeducation for everyone in the new millennium.

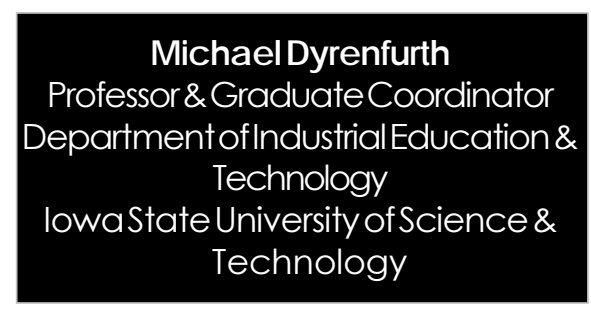

\section{Ensuring the Future of Tec hnology Education}

Technology eduation will have a future regardless of whetherwe will be a significant part ofit! We seem to be seeing only parts of the puzzle. Where is our profession's perspective? The sameperspectivethathasengagedus so actively in conceptualizing models of technology thatenable ustounderstand and develop understanding of technologyseems to be missing in our ownwelt-anschauung whenitcomes to ourview on technology. Why don't we see a continuum of programs, each important in its own right, linked inamultitude ofways toformacomprehensivenetworkofopportunitiesforeach memberinoursociety?

Weseeminstead tobedoomed toa perpetual panoply ofattempts to "position" ourindividual facets of the professionin afutile attempttooutmaneuver otherfacets of education. With all the characteristicsofbraggadocio, weseek to developrationalesthatareintended todrivehome ourimportance toothers who we apparently think are decision makers. This is like whistling in the dark to muster our courage! We seem to think thatwearerelegated to anongoing inferiorposition. Clearlywe need to raise our ownself-image!

Butwhatelse needs to happen? In my view, itseems we should concentrate on the taskathand, namely, help- ing people developanunderstanding of and capability withtechnology. This wouldrequire thatwe actively collaboratewith ourpartnersintechnicaleducation, vocationaleducation, elementaryeducation, industrial andengineering technology, engineering and science, and industrial training. You say we are doing thatalready! Really? Ifso, then why despite our acknowledged nationwide shortage of technology teachers can we notsee a single joint initiative where the combined efforts of the ITEA, NAITTE, CTTE, TED of the $A \vee A$, and others are converging on this crisis?

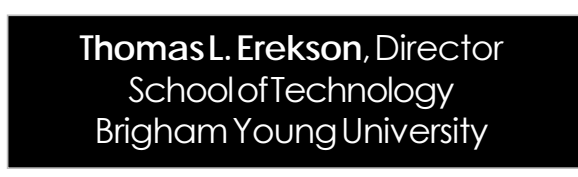

There is an old saying that the more things change the more theystay the same. This is the case with technology education (andits predecessor, industrial arts).

As a profession, we have experiencedsignificantchangesinthe transition to technology education. However, the issues confronting us are strikinglysimilartothosewefaced decades ago. It is troubling to realize that the general conditions of our profession that existed in 1959, when M. Ray Karnes penned "Improve or Perish," appear to be prevalent today. As in 1959, technologyeducation currently facesreducedbudgets, increasedcompetition from required courses in the curriculum, and to some extentalack ofrecognitionandacceptance. Why? The profession seems to lack focus, evidenced by a wide variance in programs:somehaveremainedindustrial arts shop programs, yet others are on thecuttingedge of theinformationage. Why?

The complexities of the situation do notlend themselves to simpleanswers. However, frommy perspective the answeris groundedinleadership, or the lack thereof. In years past there was strongstateandlocaleducationagency leadershipfortechnologyeducation(industrial arts), aswell as dynamic leadership in universities involved in preparing technologyteachers and supervisors. This leadership also found expression instrongstate and national professional associations. Wecanreviewour history and name the strongleaders of thepastand, tosomeextent, lamentthe perceiveddearthofstrongleaderstoday.

Did formerleaderslay afoundation that assured technologyeducation's placeasanintegral componentofstrategic importance in education in the 21 st century? If they did, why are we still trying toidentify the critical changes orimprovements needed to securea place fortechnologyeducation in the nextcentury? Wehadstrongleadersin the past, but there was little unity in the profession. The philosophical conflicts among the pastuniversityleaders, and to some extent the state supervisors, is well documented.Strongleaders, with their devoted disciples, often created conflictswithinthe profession. Wespent ourenergiesinfightingratherthancommunicating to the education community and to the public atlarge the great benefitsstudents accruethroughtechnologyeducation. To assure thattechnologyeducationisanintegral componentofstrategicimportanceineducation in the 21 st century, our profession needsunifiedleaderswhowill develop a shared vision for our future. Without ashared vision, technologyeducation will never fulfill its potential in educating the youth of today for the world of tomorrow. In his book The Fifth Discipline, Peter Senge (1990) noted that "...few, if any, forces in human affairs are as powerful as shared vision" (p. 206). He further stated that "when people truly share a vision they are connected, bound togetherbyacommonaspiration" (p.206). Peoplewith a shared vision "create a sense of commonality thatpermeates the organization and gives coherence to diverse activities" (p.206). Technologyeducation needs a shared vision-a vision that will provide coherence within our profession.

Senge (1990) noted that a shared vision is "a force in people's hearts, a force of impressive power" (p. 206). However, the vision must be shared. A vision developed by an individual, ora small group, that is imposed on an organization (ora profession) tends to "commandcompliance - notcommitment" (p. 206). Perhaps trying to "impose" their personal visions is why our pastleaders, and their disciples, were unable to secure a foundation for our programs (and profession) as an inte- 
gralcomponentineducation.

Thebenefits thatstudents derivefrom technology education are critical to preparing them for life and workin our technologicalsociety. Wemustrealize, however, thatsometimeseventhebest ideas fail to gain recognition and acceptance.Senge (1990) indicated that "new insights fail to get put into practice because they conflict with deeply held internal images of how the world works, images that limit us to familiar ways of thinking and acting" (p. 174). Sengeindicated that the "familiarways ofthinkingandacting" arementalmodels.Mentalmodelsare verypowerfulas theyaffecthow weviewthings, andwe tend to view new things through the lens of ourpastexperiences. Womac (1998), whenspeaking of mental models, stated that "weneed tobeopento newideas and share ourmentalmodels." Vision, mental models, and unity are neededin ourprofession.

If technology education is to becomeanintegral componentofstrategicimportance in the total education enterprise of thenewcentury, weneed to: (a) learn fromourhistory, butnot be controlled byit; (b) be willing to move out of ourpersonal comfortzones; (c) change ourmental models, ifyou will, as a precursor to developing a shared visionforourfuture; (d) developashared vision; and (e) develop and support leaderswhocanguidetheprofessionin achieving that vision.

\section{References}

Senge, P.M. (1990).The fifth discipline:The artand practice of thelearmingorganization. New York: Doubleday.

Womac, R.J. (1998, October). The future of Visteon, an enterprise of Ford Motor Company.SpeechdeliveredattheElectrical Manufacturing and Coil Winding Conference, Cincinnati, $\mathrm{OH}$.

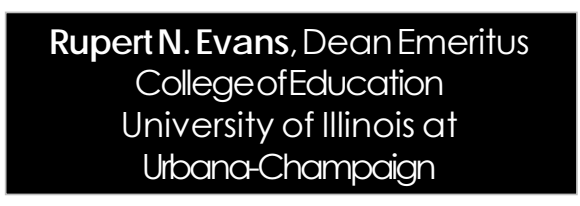

This is a tribute to Dr. Harvey Dean ofPittsburg, Kansas, whohasdonemore than any otherperson to change the face oftechnologyeducationin thelast quarterofthe20thcentury. Unfortunately, heisnotamemberoftheMississippiValley Conference,andhemayevenbeunknown tosomeofitsmembers.

Whathas Harvey Dean done? He has designed asystem of equipment, furniture, and instructional materials fortechnologyeducationinthemiddle school. He did not do this in a university, but through his own company, Pitsco. Hehas plowed back the profits from the sales of these teaching modules into further development of his system and into its dissemination. The result is that more than 1,500 middle schools are using his curricula, farmore thanhaveeveradoptedtherecommendations of tax-funded curriculumstudiesconducted byuniversities.

As do all innovators, Dr. Dean owes greatdebtstosome ofhispredecessors. In the second quarter of the 20th century, William Warner developed the conceptofa "Laboratory of Industries" at The OhioState University. His organizationforinstructionrotatedstudents from one instructional position to another. It used space and equipment efficiently, butfewinstructorsseemed abletocopewithteachingsuchawide variety of simultaneous tasks.

In the third quarter of the century, Don Maley of the University of Maryland developed a revised curriculum based ontesting and experimentation rather than the construction of takehome projects. During the same period, Henry Ziel, at the University of Alberta, used a similar curriculum but improved the effectiveness of instruction by providing self-teaching media ateach teachingstation, thus conservinginstructorenergyandsupplementing theinstructor'spersonalknowledge. Heworked todisseminatehisconcepts, butfewprofessorswerewilling tolearn.

As the last quarter of the century began, Harvey Dean began to use his company as a vehicle for curriculum development. Idonotknow why Professor Dean left a university setting to develophisinnovations, but ldoknow thatfewuniversitieshave beeninvolved in studying, let alone promoting, his ideas. Othercommercial firms certainly are aware of his successes. One company after another has begun to sell modules that have more than a faint resemblance to the Dean (and Ziel) instructional materials and processes. Are universities not involved because they are afraid of using technology in technologyeducation? Orbecause of the "NotInvented Here" syndrome? Or because university faculties are less in touch with what is really going on in schools than are Dean and his competitors?

A keyquestion facing the Mississippi Valley Conference is "Howshoulduniversitiesbeinvolvedintechnologyeducation?"Atonetime, manymembers of the conferenceworkedhardtoreshape industrial arts and all of them prepared teachersforsecondaryschools. Today, the members are much more likely to betraining technologists orinstructional administrators whoworkin business or industry. However, in response to the recentincreaseindemandfortechnology education staff in secondary schools, some universitieshaverevived their teachereducation programs. Intermittentattention to teachereducation is understandable, but it is not desirable.

Thereisanevenmorebasicproblem than periodicteachereducation.Major changes are occurring in technology education, butthey havelittlerelationship to what universities have been doing in the last quarter century. If universities are to be involved in technologyeducation, they also must be involved in curriculum development that consists of more than preparing endless lists of goals. Harvey Dean has setan example forus. Arewe willing to acceptthechallenge?

P.S.Ihavenorelationship with Pitsco or any other company producing instructional materials for technology education.

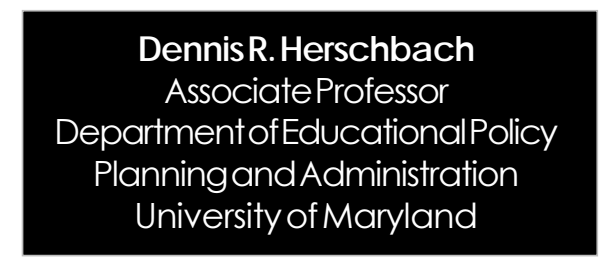

\section{Looking Past2000}

Subjectfields in theschool donothave an inalienable right to a secure and permanent niche in the curriculum. Theymaintain theirplace in the school through the supportofaneducational public that valueswhat thesubjecthas to offer. For this reason, most subject fieldsareconstantlybalancing theirown professional identity with changing public priorities, altered perceptions 
aboutschooling, and a largerpedagogical climate that itself is changing. Subjects that continue to projectvalue totheeducational publicprosper; those that do notreflectvalue cease to exist. Somesubjectssimply totteralong foran extended period of time, unable to fully articulatetheireducationalimportance until they lose so much support from theeducational community that they, too, sink into oblivion.

Technologyeducationhasconsiderable potential togenerate substantial public support. However, the subject field is floundering in uncertainty. Ithas notbeen able to define itself in terms thatappeal to theeducational public's deeply held beliefs and values concerning what should be taught, why, and to whom. There are at least three majorchallengesthatmustbesuccessfully confronted in order for the field to continue to play a significanteducational role in the next century.

First, and most important, technologyeducationhastofocusonhowbest itcanservestudents. Lesstimehastobe spentonspeculatingabouttechnology itself, and more in finding out what parents and students expect from the field and how we can translate these expectations into programs that will address theirimmediate and concrete education concerns. How doestechnologyeducation, for example, help youth achieve in school, prepare for jobs, pursue postsecondaryeducation and training, andentersuccessfullyinto adulthood? Unless the field canrespond satisfactorily to such concerns, it will notbe able to mobilize public support behindtechnologyeducation. The beginning point of programming is not technology. It is parent and student concems.

Second, the field has to build on what is probablyits strongesteducationalsuit.Technologyeducation best can be conceived as an interdisciplinary, activity-based subject field that offersstudents theopportunity to apply knowledge to the solution of practical, technological problems. The words interdisciplinary and activity need to be stressed.Perhapsnoothersubjectfield in theschoolofferssuchanopportunity forstudentstointegrateknowledgefrom interrelated fields of study as they engageinself-directedactivitysituatedin areal-worldcontext. However, thepro-

fession has been painfullyslowin making its case to the educational public.

And third, it is crucial to generate support within the largereducational community of whichtechnologyeducation is a part. The field has been too inwardlooking andself-occupied. One is struck, for example, by a seeming lack of rigorous, systematic thinking aboutcuriculum planning thatlargely ignores currenteducational reformeffortsandemerginglearning theory. Yet, if the fieldisunable to engageinmeaningful dialogue with the greatereducational community, it cannotexpectto draw on support from this same community asitstruggles to define its place in the school curriculum.

\section{DanielL Householder, Professor Department ofEducationalHuman ResourceDevelopment Texas A\&M University}

If technologyeducation is to be an integral componentofstrategicimportanceintheeducationalenterprise, the professionmust:

1. Expand the intellectual foundation of the field beyond design, manufacturing, construction, communication, transportation, engineering, and architecture toinclude the full range of techniques for changing and controllingthenaturalandhuman-madeworld.

2. Explicate arecognizable body of technologicalknowledgeand practice toserveasaresourcebasefordesigning instruction.

3. Evolveunique comprehensivecurriculumdevelopmentstrategies tointegrateknowledgeand practice withcontemporary understanding of the way learners acquire knowledge and skills.

4. Explore and value the differing meanings individuals and groups ascribetotechnologyso thatappropriate programsmaybedesigned tointegrate within their individual and cultural framesofreference.

5. Examine the impacts of technologywithinanduponcontemporarycivilization with a clear and critical vision to ensure the highest quality of life for futuregenerations.

6. Explain the contributions of technologicalstudiesinmoreeffectiveways, targeting keystakeholders who can position the field at the center of the educationalendeavorincommunities, states, and nations.

7. Expand teachereducationto provideandimplementacomprehensive scheme to prepare teacherswhocan exciteyoung peopleabout thestudy of technology.

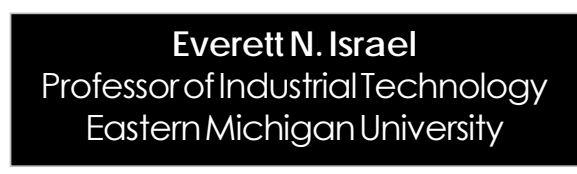

\section{The Future of Tec hnology Educa- tion: Meeting the Challenge}

At no time period in our history has there been such recognition that all elementary, middle, and high school students mustunderstand the role of technologyinsocietyand culture to be well-educated citizens. The general public and subjectmatterexperts are beyond giving lip service to this universal tenet; they wantaction. Manynational curriculum projects and standards are implementing the study of technologyin the general education curriculum. Parents are being turned onbyoutstandingtechnologyeducation programs. The ITEA has beensuccessfulin developing collaborativerelationships with major national associations and developing long-lasting relationships with key shakers and movers.

The time is right for the technology education profession to generate the critical massneeded to have technology required as part of generaleducation for all K-12students. The questions are, Canthetechnologyeducationprofession work togetherand withothersto develop and implementastrategy in whichparents, educators, professional associations, business andindustry, and govemmentwilldemandeducationprograms that will help future citizens to understand, be able to apply, and appraise therole of technologyineverydaylife? Will the technologyeducation profession create the critical mass that results in others demanding that the study of technology berequired of all students? One can't push a string to moveanobject, butotherscanbemotivated to pull arope to createa critical mass.

Once the study of technologybecomesapartofgeneraleducation, can the technologyeducation profession ensure thatteachersareable to deliver 
qualitytechnologyprograms? Canthe profession develop creative ways to ensure that teachers fromanumber of differentsubjectmatter areas will join withtechnologyeducationteachersin developingqualityprogramsandkeeping themcurrent?

Will technology teachereducation programsmakethenecessarychanges toprepareteacherstodevelopandteach qualitystand-aloneandintegratedunits of instruction, curricula, courses, and programsabouttechnology? Will currentandfuturetechnologyteachereducators remove the blinders of the past and createnewandeffectivesolutions forpreparing and certifying teachers? Make ourdreams becomereality! The time is right to take action, to work togetherandmeetthedemandforquality teachers. Anoptimistic attitudeleads to creativesolutions and createsapositive and productive professional work environment.

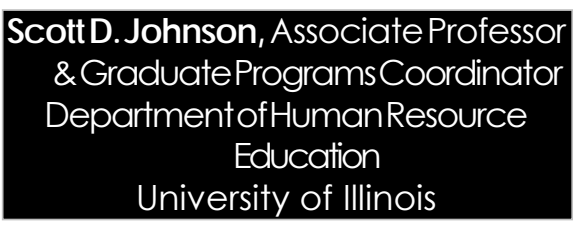

It is difficult to imagine the field of technologyeducation component of strategicimportanceinthetotaleducational enterprise. While we in the field have devoted ourprofessional careers tomaking thishappen, we havemade little progress this century and the prospectsforsignificantchangein the future appearbleak. The biggestbarrier that prevents technologyeducation from becominganindispensablecomponent of the school curriculum is, in myopinion, society'sperceptionthattechnical courses and nonprofessional jobs are desirable only for those who are less brightandless affluent.Parents expect theirchildrentoattendcollegebecause theybelieve that goodjobs are available only to college graduates.School boards and superintendents promote theirschool systems by publicizing the collegeacceptanceratesoftheirgraduates. Universities further support the public'sperceptionbyraisingacademic requirements for admission and refusing toaccepthighschoolcourseworkin applied physicsandmathematics. This is a deeply rooted societal problem.

Unless there is adramatic economic decline in the future, it is unlikely that the public's value for technical work will change without significant effort onthepart of the profession. Atthevery least, three majorinitiatives need to be implementediftechnologyeducation isto becomea truly valued component within America's schools. First, critical alliances with industry, professional associations, andgovernmentagencies will need to be established. At the national level, ITEA has made progress towardsuch alliancesinrecentyears, butmore must be done, especially at the state and local levels. Such alliances will provide the critical mass of influentialleaders and decisionmakers needed toswaypublicperception.Second, technologyeducationmustgaina foothold in the elementary curriculum while children are stills self-motivated to learnandwhereparentinvolvementin schooling tends to be greatest. Technologyeducation canbecomeafoundationin the elementary curriculumby providing amotivating, hands-oninterdisciplinarylearning experience that fosters creativity, motor skill development, and an understanding of basic principles ofsciencethrough theapplication of technology. In addition, a strongelementaryschoolpresencewill enhance future enrollmentinsecondary-level technology programs. Third, technologyeducationneeds tobetter serveallstudents, collegebound ornot. The unfortunate battles of the past argued the benefitsofageneraleducation versus a vocational focus for ind ustrial arts. This hindered the opportunity for technologyeducation toevolveintoa multifaceted program thatprovidesoccupational skills for those who will entertheworkforceupongraduation, appropriate experiences for those who will pursue technical programs in communitycolleges, andapre-engineering emphasisfor those who will attend university-level engineering programs. Technologyeducation should model its curriculum breadth after other programs such as mathematics, where a range of courses, such as basic math, technicalmath, andcollegemath, serve allstudents.

These three initiatives, establishing critical alliances, creating apresencein theelementary curiculum, and broadening the programemphasistoserveall students, are the criticaleventsneeded toestablishtechnologyeducationasan integral componentofstrategicimportanceforeducationin thenextcentury. Each of these initiatives can help build publicsupportfor thestudy of technologythroughaproactive process of collaboration, networking, and systemic educationalreform.

Theodore Lewis, Associate Professor

Department of Work, Community \& FamilyEducation,

University ofMinnesota

\section{From ThisDay Forward}

Technologyeducation will have to admit to both generaleducation and vocational purposes. The field has to do this for the following reasons. The nature of workand vocationsis changing. Work today has to be infused with knowledge. Workershavetobeaseducatedas theyare trained. Weneednot fear that a vocational purpose means narrowlyconceived programs. Indeed, vocationaleducation has beenstriving torecastitself throughintegration with academiceducation.Technologyeducation can offer children their first glimpses of careers and, more generally, of work life. This is not new, of course.Calvin Woodwardhad offered a similar analysis in 1863 when he wroteaboutthebenefits ofmanual training. Childrenintechnologyeducation classes, especially in the high school, should become technologically capable. That is, they should become proficientin the use of computers and in applicationswhere computersinterface with machines. They should also bereasonably proficientin tooluse. In summary, technological literacy and technological capability are to be the goals, whereliteracymeans disposition and capabilitymeanscompetence.

All education is ultimately vocational. It is always unnecessarilyidealistic to pretend that forms of schooling areimpervious to the labormarket.For example,competenceinmathematics ismuchsoughtafterbyemployers. Technologyeducators need toseek toconnect their discourse within the mainstream of education. Wegenerally talk among ourselves. As a result, the field remainsan outsider despite more than acentury of solid existence in the public schools. 
Technologyeducationhastolookto nontraditionalways ofrecruiting teachers.Manymid-careerengineerswould begoodcandidatesforteaching positions. We have to figure outways to do this. Ithink that in Wisconsin and Florida there are such programs. AtStout, Len Sterry is involved with non-traditional certification. Thisisthefuture.

We should pay more attention to connectionsbetweentechnologyeducation and art. William Micheels used to emphasize this with us at Stout. The point isstill valid. The focus has to be on creativity. Weneed tospendmoretime helping childrenidentify and define as well as solve problems. Recognizing and defining the problem should be given as much prominence as solving it. Letchildrenlook around theirhomes andcommunitiesforproblems that they thinkrequire asolution. If we can inculcate thatdisposition, wewould behelping them tobetterunderstand the work of technologists.

Finally, technologyeducation can provide context for other areas of the curriculum beyond art. We can take advantage of the widespreadinterest nowin "situated cognition," thatis, the need to placelearning in context. We havetomoveoutoftheshopsandreach out to others.

DonaldG. Lux, Professor Emeritus TechnologyEducation

The Ohio State University

\section{Changelmperatives}

Technologyis abodyofknowledge thathasbeeninstrumentalin determining the winners and losersin the search by humanity for a more secure, efficient, and rewarding way of life. Most simply put, it is the body of knowledge of efficientpractice, whetherthatpracticebeharvesting, making music, healing, and so forth. Given its role in mankind's very existence, it is indeed puzzling how its role in formal education has been almost completelyoverlooked.Perhaps thismaybeattributed to the fact that throughout much of mankind's historyone eitherbecame anaccomplishedstudentoftechnology orwas short lived. The value of knowledge of practicewastakenforgranted, and the beliefthatitwouldbeabsorbed

by simply growing up in our culture confounded thesituation. Eventoday technologylargelyis notseenas apart ofbasic formaleducation.

If the aboveis true, then the firstand perhapsmostimportantchangetechnologyadvocatesmusteffectistocreate acompelling information program that will convince the public of the importance of knowledge of practice and of public literacy in this body of knowledge. Concurrently, a massive effortmustbemadetogatherexamples of existing programs thatcanbeseento contributetotechnologicalliteracyand toliberal education in the 21 stcentury. These mustbegivenwide exposure as an essential component of the public information program. These demonstrationprogramsmustbelaboratorybased iftheyare to be believableasexamples ofstudentsstudying knowledge of practice. Actual participation or practice is an essentialelement of knowledge of practice. Just as music appreciation classes do not teach one how to play music, listening toverbiageabouttechnologyand/orwatchingotherspractice technology will not result in learning technologicalknowledge. Ourpictures mustmake it clear thatwe teachskills as an integral part of technological knowledge.

If thisprogramis effective, the public will come to see that technological literacy is essential to our survival, to the protection of our freedoms, and to the advancement of our culture and prosperity. There is nothing wrong with technologyeducationinconcept.Our fault lies in our inability to present a clearand convincing explanation of what technology is and what it can contributetoeffectiveliberaleducation programs.

The ultimate end of these changes should betomakeknowledge of practice (technology) the core of public liberal education from preschool throughoutlife.

G.Eugene Martin, Professor and Dean

School of Applied Arts \& Technology Southwest Texas State University

\section{WhereAre Ourleaders?}

Technologyeducation professionals nationwide will argue that there are manycriticalchangesorimprovements that mustoccuriftechnologyeducation is to be an integral component of the educational enterprise. However, there is one change orimprovement that reigns supreme above all others. Today, there is a lack of sound and substantialleadership among therank and file within the profession-we are becoming aleaderless profession.

The technologyeducation profession in the UnitedStates (and probably internationally aswell) needs a mass of peopleatall levelsofeducation, whether they be at the local, state, or national levels, who are willing to step forward to provide a new level of leadership. The profession is in dire need of people who want tolead, who want tolearn howtolead, and whoare committed to leading throughout theirprofessional careers. Developing professionalleadership teams is very important, if not mandatory, for oursurvival.

The profession needs to make sure thateveryfuture technologyeducatoris aleader. It needs people who know how to frame the critical problemsfacing the profession and thenlead other peoplein the developmentofplausible solutions to these problems. This will requirethatleadership developmentbe a very important part of the teacher education curiculum. Leadership training must start now, not tomorrow, if there is to be any significantchange in ourposition in the educational enterprise. Theremustbeaheightenedconcernabout the need forleadership development within the profession. Leadership, or the lack of it, must be addressedimmediatelyif the profession is to play a critical role in the educational enterprise of thenewcentury. Thisproblem deservestheundividedattention of all people in the profession. Unfortunately, at this point in time, I do not sense an uprising in the profession to address this issue. Isit possible that I am incorrectin my analysis of the need for leadership and the role strongleadership could play in leading the professioninto the coming century? 
Jerome Moss, J r., Professor

Emeritus

University of Minnesota

\section{Connections}

The defining characteristic of the field of study we now call technology education has always been to make things using the tools, materials, and processes thatillustrateselected technologies of the times and theirimplications for the individual and society. As the field has evolved since thelate 19th century, manyattemptshavebeenmade to justify its place in the K-12 curriculumbyreinterpretingitsbenefitsinterms appropriate to extant cultural conditions. And yet, despite these efforts to remaineducationally and socially significant, othereducators and the public persist in perceiving the field, and justifying its value, in terms of limited utilitarian benefits to the individual: boys (mainly) learn to make and fixuseful things, and they sometimes (incidentally) benefit occupationally from the experience.

Whatreinterpretation ofitspotential benefits mightimprove the field's perceived and actual value in the K-12 curriculum during the next century? One promising approach is to capitalize upon the field'smanyopportunities for building "connections" within the school curriculum. Technologyeducationneeds tobeseenasimportant, not only in its own right, but also for its contributions to the greater effectiveness of other subjects. By using its methodological practices as well asits content, technologyeducationcanbecome viewedas agender-free, integral, and critical part of a coherent total school curriculum.

Offering hands-on, realistic experiencesintechnologiesis the methodology of the field. It supplies the functional context for demonstrating the applications and enriching the meaningofmanyabstractconceptstaughtin mathematicsand thephysicalsciences. The method provides opportunities for building cognitive capabilities. Simulatedexperiencescanalsoenlivenboth civic andethicaleducation byillustratinghowtechnologicalchangecanbe used either to facilitate or to block progress toward the goals of a demo- cratic society. Thisintegration (ormore accurately, coordination) of subject fields canonlybeaccomplishedwhen technologyteacherssee otherfieldsas opportunities for collaboration rather thanas competitionforcumicularspace, when they are willing to expose their ideas to thescrutiny of teachersinother fields, and when they are able to plan cooperatively.

Asvocational education redefines itself, vocational curricula are becoming less specialized. At the same time, theacademicsubjects arebecoming moreconcemedaboutpracticalapplications beyond schooling. The time is propitious to exploit, rather than resist, thenatural connectionsbetweentechnologyeducationand the world of work. The occupationalimplications of technologiesandtechnologicalchangeprovide a rich resource for exploring a wide variety of careers. Technology educationteachersshould deliberately plan and provide for a wide range of experiences that helpstudents learn about themselvesinrelationtorelevant occupations. And the planning should bedonecooperatively with vocational teachersso that the overall career developmentofstudentscanbeaccomplished as efficiently as possible.

Theidea of "connections" for technologyeducationis, of course, notnew. Somescholarshave writtenaboutvariousaspects ofit, andsometeachersare attempting to practice parts of it. But if technologyeducationis to make asignificantimpactontheschool program in the next century, thenconnection needstobecome thenormratherthan theexception.

Stephen Petina, Assistant Professor University of British Columbia

\section{It's 1999: Are We Part of the Problem orPartofthe Solution?}

\section{"What's past is prologue,"} Shakespearewrote. Neitherahistorian nor a citizen of the 19th or 20th centuries, Shakespearehadaprescient grasp of humanity. In our time, we in the industrialized world walk the thin line between Shakespearean selfdestructionandfulfillment. We'vebeen wretchedin our continuation of gross inequities between cultures, in ourmismanagementofourknowledge, andin ourannihilation of much of ournatural inheritance. We've also been able to recover from our most self-indulgent acts and are learning to celebrate our capacities for compassion, conservation, andlove. Wearelearning to attend to our past along with reassessing our myopic and often technocentric visions of the future.

At this particular juncture in time, education is situated in a precarious position. Withacheckered pastofeducating for cultural imperialism, competitive, patriotic nationalism, religious intolerance, and "progress" at anyexpense, it'suncertainwhetherschooling is part of the solution. In the United States, a separate system ofindustrial schoolshasmaintainedseparatefunds ofknowledgeforAfrican descendants, Asians, Hispanics, and Native Americans on one side, and for European whites, generally, on the other side. Lessraciallydiverse, Canadamaintained aseparateindustrial educationsystem for their aboriginal children that, as in the UnitedStates, wasinferior to that for White children. The legal system changedsegregation practicesinboth countries during the 1950s and 1960s, butbyno meanswere conditions altered. A recent documentary by Jonathan Kozolshowed that in thelate 1990s, "savage inequalities" continue in the technologyeducation of suburbanandinner-citystudents of the United States. In the Cleveland area, for example,suburbandistrictssuchas Maple Heights enjoy new modular technology facilities and a large budget for consumablesupplies. The Cleveland inner-cityshops continue tolimpalong with leaky roofs, warped floors, and surplus drill presses from the 1920s.

But along with racial inequalities, technologyeducationreproducesgender and class inequities. A separate system of industrial education forboys andgillsmaintainedgenderdifferences inknowledge andmobility throughout this century. Generally and especially at the secondarylevel today, students andteachersintechnologycoursesare male.Theschoolsysteminboth Canada and the UnitedStates continues to provide separate education for collegebound and vocationalstudents, demonstrating class differences rooted in century-old practices. Working classes continuetobeshortchanged, andtech- 
nologyeducatorsin the UnitedStates have turned theirbacks. In most technologyeducators' discourses, it's difficult to find any references to labor (Petrina, 1998a, 1998b). In terms of class, gender, andrace, it's not clear thattechnologyeducationispartof the solution.

Forthepastcentury, we'vemanaged to alignindustrial and technologyeducation witheconomic interests. In the latter third of this century, technology educationwas definedinterms of competitivesupremacy.IntheUnitedStates, this continues unabated. The new NationalStandardsforTechnologyEducationwererecently constructed, according to the project's director, "to enhance America's global competitiveness in the future" (Dugger, 1995, p. 4). Technological literacywasconstructed in the same base, economic terms (Petrina, in press). Country is pitted against countryineconomicstakesthat haveplacedincredibledemandsona dwindlingnaturalinheritance. Itdoesn't muchmatterto technologyeducators that $20 \%$ of the world's richest nations use $80 \%$ of the world's resources. It doesn'tseemtomatterthatonequarter oftheworld'spopulationdoesnothave basic necessities such as clean water, food, and shelter. The average American consumes 120 pounds per day of resourcesandthrowsawayfourpounds ofgarbageeachday. Everytimeatechnologyeducatorteachesstudents that winning the economic stakes is America's destiny, the pathispavedfor agluttonouseconomyout of control.In ecological terms, it'snotatall clear that wewant to be part of the solution.

"Good"technologyeducationcontinues to be aboutlifestyle changes. To bepartof thesolution, technologyeducators ought to model areduction of consumption and production in their own lives and in their labs and shops. Goodtechnologyeducationmeansrecovering "Depression-era" valuessuch as compassion, conservation, dignity, frugality, modesty, and simplicity. Our natural inheritance is not ours to exploit.Those ofusteaching in privileged countriesoughttoencourageourpeers and students to live simply so that others may simply live. Good technology educationmeanstakingequityseriously and sharing powerwith our sisters and brothers of color. Those of us in posi- tions of power ought to muster the will to say "no" to competitive economic stakes, to exploitive practices of globalization, to homophobic aggression, to raciststructures, and to sexist displays ofmasculinity. Good technologyeducationmeans that our fair, gentle, and just practices of the past are the prologuefortomorrow.

\section{References}

Dugger, W. (1995). Technology for all Americans. The TechnologyTeacher, 54(5), 3-6.

Petrina,S. (1998a). Menatwork:inspecting the foundations of technologyeducation. Journal of Industrial TeacherEducation, 36(1), 99-121.

Petrina, S. (1998b). The politics of research intechnologyeducation.JoumalofTechnologyEducation, 10(1), 27-57.

Petrina, S. (in press). The politics of technological literacy.International Journal of TechnologyandDesignEducation.

\section{David J. Pucel, Professor Department of Work, Community \& FamilyEducation \\ University ofMinnesota \\ TechnologicalLiteracy:An Essential Ingredientforlife and Careers}

Technologyanditsimpacthavebeen acknowledged as major concerns of society. "Itis...commonplacethatmodernscienceand technology....areleading forces..." (Rapp, 1989, p.x). Technology, defined as "the application of knowledge, tools, and skills to solve practical problemsandextendhuman capabilities" (Johnson, 1989, p. 1), impactsall of us. However, when asked to define technology, most people think ofsuch particularobjectsascomputers, the space shuttle, or cellular phones. Theyarefascinated with what technologyproduces, butfewhave anunderstanding of whattechnologyisas a field of study or how technology evolves. Brockway (1989) suggested thatpeople whocannotadequatelyunderstandand dealwithtechnologyare "techno-peasants," serfs of technologyrather than masters of technology. This suggests that technological literacy must be viewed as part of general cultural literacy if people are to be able to fulfill their roles as citizens within a techno- logicalsociety.

Within this evolving context of the increasingimportance oftechnological literacy, themostimportantchangethat can take placein the fieldisfortechnologyeducation professionals to clearly communicate theimportance oftechnological literacy to society and the importantrole technologyeducation can playin providing thatliteracy.Such literacy is foundational both to citizenship and to becoming economically productive citizens. However, in order to deliver the type of education required, technology education must adoptphilosophical and methodological premises, which can actually facilitate the preparation of technologically literate individuals. Teaching strategy can nolonger be limited to the use of lock-step modules of instruction in whichstudentshavelittleornochance to innovate or to truly understand the technology underlying the activities. Wemust teach basictechnologyprinciplesand providestudents withopportunities toproduceinnovative butworkable technical solutions to real problems. Italsomeans clearlyrelating technologytostudents' visions and expanding theirperceptions of what the future may hold for them. Since work and careers areasubstantial portion of most students' visions, technologyeducators mustdiscontinue the view thattechnologyeducation and careereducation are antithetical. Current leadership needstoabandonpastfeudswithtraditional vocationaleducationandcreate new models for viewing the role of technologyeducationincareerpreparation. Neither technologyeducation norvocationaleducationbased onindustrial or information-age views will meettheneedsofstudentsas theyenter thenewknowledge/imaginationage. Technologyeducation should provide basic skills and understandings of technology, which obviously are required andappliedincareers.

A major challenge to the prospect that technologyeducation will assume this majorrole in the future education ofsocietyis the preparation of teachers. Teachers will need tobe prepared with increased understandings of the sciencesunderlying technologyand with the technical skillsinvolvedin applying technology. Iftechnologyeducation is going to make a claim that it is funda- 
mental in the education of students who will be able to understand and apply technologyinimaginative and innovativeways, teachersmustbeable tofacilitatestudentinnovation. The current practice of diminishing the role of theteacherbyprovidingmodulesleading to pre-determined solutions and suggesting that theteacheronlyneeds to be afacilitator, onlymakesmockery of the true essence of technological literacy, which suggests the ability to applytechnologyininnovativewaysto solvehuman problems.

There is a major role that society needs to have filledregarding the developmentofatechnologicallyliterate society. Can technologyeducation deliver?

\section{References}

Brockway, J.P. (1989, August 11 1). Technology \& the liberal arts: Mixing differing thought patterns. Wellesley, MA: Wellesley College, Alfred P. Sloan New Liberal Arts Program.

Johnson, J. (1989). Technology: Reportof the project 2061 phase I technology panel. Washington, DC:AmericanAssociationfortheAdvancementofScience.

Rapp, F. (1989). Introduction: General perspectives of the complexity of philosophy of technology. In Paul T. Durbin (Ed.), Philosophy of technology (pp.ixxxiv). Holland: D. Reidel.

\section{WillisE Ray, Professor Emeritus} The OhioState University

Ratherthanattendingtotacticalqueriessuchas "Whatare the mostcritical changesorimprovements thatmustbe made?" thismini-treatise addressesan oftenused,morecomprehensiveframework of higherorderquestions. Leaders in the profession, especially those who are members of the MVTTEC, should seek answers for and create solutions thatrelate to these fourstrategic questions: (a) Where are we going? (ends question); (b) How arewe going toget there? (means question); (c) How will weknow thatwe have arived? (valuation question); and (d) What are the optimumsupportsystems that are required? (sustenation question). These questions are as critical for technology teacherpreparation cumiculaastheyare forschool-level, other collegiate, and adult-continuingtechnologyprograms.
Due to an imposed "carefully chosen words" restriction, what follows will notmeetwith the approval of those whowishtoread fullsentencesand/or contemplatethethrustofproperlydrawn paragraphs. The words and phrases below are meant simply to provide flashes of light, which may cause even greaterthoughts. Considertakingsome of the following actionstohelpproduce aviable program for 21 stcenturytechnologyeducation.

The Ends Question.Promote technology as a significant and growing domain ofknowledge ("knowhow" to do efficiently) and distinguish this knowledge from the products and servicessuch knowledge produces. Differentiatetechnologyfromlanguageand mathematics (formal knowledge), the humanities (prescriptive knowledge), and the sciences (descriptive knowledge). Exploit the supportiverelationshipsbetweenandamongthehumanities, science, mathematics, and technology. Expoundupon the general, liberaleducationfunctions of technology as well as the pre-employment and employment education purposes. Codify a distinctset of concepts, principles, and generalizations of technology that may be reinforced through doing experiences for each level of schooling (i.e. primary school, middle school, high school, postsecondary vocational, technical, andengineering studies, and adultand continuing education). Establish "technology" as a schooling curriculum organizer, with contentandsubjectmatterdistinctfrom otherschooling programs.

The Means Question. Develop publicsupportfortechnologyeducationat all levels by planning, organizing, and controlling public awareness promotions. Organize student groups (TSA and TECA, forexample) as integralextensions of ourinstruction. Improve applications of traditional teaching methods of lecture, discussion, demonstration, discovery and problem solving throughexperiments and projects. Createinstructionalmaterials (comprehensive courses as well as modularunits of study) that sample, systematically, at equallevels of generality orspecificity, thetotalmatrix/array of the technology knowledgebase.Prepare teaching/ learning unitsfor Internet/Web delivery bypersonalcomputers (the IACP staff dreamedaboutsuch deliverysystems, but the world and wewere notready). Experiment with "virtual learning" approachesand "distancetechnologies." Approach corporatemediagroupsto place in cyberspace organized treatmentsoftechnologyeducation.

The Valuation Question. Adopt/ adapt, butmake use of, the Standards forTechnology Education Programs covering the programelements of philosophy, instructional programs, studentpopulations served, instructional staff, administration and supervision, supportsystems, instructionalstrategies, public relations, safety and health, and evaluation. Improve all approaches to assessinglearnerachievementintechnology. Encourage statewide testing programs, whichincludetechnologyas aprogramarea.Promotetechnologyas a program area within a voluntarynational testing program. Sample, periodically, thereaction ofschooladministrators andotherprofessional colleaguestoour effortstodefine, promote, andimproveour discipline.

The Sustentation Question. Participate in the program of work of the ITEA. SupporttheFoundationforTechnology Education.Contribute toothernational, regional, state, and local councils and associations. Interactwith administrators of schooling at all levels. Encourageadequatestaffingand financialsupportforprogramsupervision. Plan and haveconstructed/remodeledlaboratory facilities that are flexible.Patronize and encouragenewand existing commercial organizations that publish and distribute instructional materials focused ontechnologysubjectmatter.Support commercial companies that sell innovative curriculumandlaboratorymaterials, equipment, and devices. Continue toupgradeteachereducationprograms, using NCATE and ABET standards, amongotheraccreditingagencies.Support publicly-funded, experimental charterschoolsif theyincludeaninnovativetechnologyeducation program area.Seektoencourage/enactlegislation atthestateandfederallevelsthatwouldbe "umbrella"totheconceptoftechnologyin allofitsschoolingmanifestations.

Postscript. Surely, bynow, you have recognized that thesecommentshave come from afar, both in distance and (lackof) recentprofessionalexperience. Butifwhatissuggestedabovesparksan 
ideaortwoincurrentleaders' thoughts, the profession just could make some changesandimprovementsaswemove toward thenextcentury.

MarkSanders, AssociateProfessor VirginiaPolytechnical Instituteand State University

\section{PoliticsasUnusual}

In anerain whichtechnologyrules, technologyeducation offersone of the most compelling curriculums in all of education. Yet, few outside our field seetechnologyeducationas animportant-letalone essential—schoolsubject. This is ouridentity crisis; and when the subject turns to this, someone invariablysuggests apublicrelationscampaign. The author has been guilty of doing so on more than one occasion. But the truth is, we simply do nothave the capital to mount a public relations campaigncapable of convincing the masses to vote "yes" for technology education. Rather, wemustidentifythe relatively few who possess real influence (power) and gain theirattention and political favor. If technologyeducation is to realize its potential in the 21 st century, we simplymustbecome aggressively and outwardly political. Verylittle of real significance will happen in our field until we re-direct our energiesandresourcestoward thistask.

As we go about this business, we shouldbeawarethatscienceeducation isworking toincorporatetechnological education, as we knowit, into the sciencecuriculum. ContentStandardEof theNational Science EducationStandardspromotestechnologyeducation objectivesandactivitiesforthescience classroom (National Research Council, 1996; Sanders, 1996).Suchmajorcompetitions as the NSTA/Duracell Scholarship Competition, the NSTA/Toshiba ExploraVision Awards, and the Craftsman/NSTA Young Inventors Awards Program utilize millions of dollars of corporatesupporttopromotehands-on technologyasscience (Sanders, 1997). We should be aware that tomorrow's technologyteacherismorelikely tobe certifiedinscience thanintechnology education.Keeping thatinperspective mayallowustobemoreeffectiveinour struggle for technological literacy for all Americans.
Wehave madesomestridesinvarious political arenas over the past five years. Theauthorrecentlysurveyedstate supervisors oftechnologyeducationto assess the extent of political activity taking place (Sanders, 1998). Fifteen of the 22statesresponding described political activities underway. Massachusetts and Texas have hired lobbyists. Florida has received more than $\$ 55$ million from the state legislature over the past five years to fund technology educationinitiatives. Connecticut, Massachusetts, Minnesota, and Virginia have worked directly withstatelegislators to promote the inclusion of technologyeducation in educational reformlegislation. Connecticutand New York are formulating newstrategic alliances with the corporatesectorand the engineering community. New Jerseyis working with the Chamber of Commerce to influencestate-level policy. Virginia has successfully lobbied for high school science credit for such courses as Principles of Technology.

The ITEA has also stepped up its efforts in this regard, having identified 80 different associations with whom the Associationinteracts during theyear. The "major players" with whom they interactregularlyinclude NSTA, NASA, NCTM, NRC, NAE, NAS, NSF, NASSP, and NAESP (K.Starkweather, personal communication, August 11 , 1998). And of course, the Technology for All AmericansProjectis themostcomprehensive political activity in our field to date, havingbeguntocommandtheattention ofmany different influential parties.

These efforts are a good beginning, butwe must, as a profession, embrace the notion thateducational change is the directresultof politicalaction.Lacking the resources to sway the masses, we must focusinstead on two keypoliticalconstituencies:corporateexecutives and state politicians. We should wooconporateexecutivesbecausethey provide the clout to influence the politicians. And we must lobby our politiciansbecausestatelegislationfocused oneducational reformis currentlymotivating changeineducationall across America. Buteven when we cannot mustercorporateclout, weshould camy our tune to our politicians. Because, afterall, "technological literacy forall" is a message most Americans notonly wanttohear, butfacilitate.

\section{References}

NationalResearch Council.(1996). National scienceeducationstandards. Washington, DC: Author.

Sanders, M. E. (1996). Scenarios for the "technologystandard." Journal ofTechnologyEducation, 7(2), 2-4.

Sanders, M. E. (1997). Addressing the crisis ofidentity. Journal of TechnologyEducation, 9(1), 2-5.

Sanders, M. E. (1998, October). Political action in technologyeducation.Paper presentedattheSoutheastTechnology Education Conference, Greensboro,NC. (http://teched.vt.edu/Sanders/ PoliticalAction 1.pdf)

EmestN.Savage, Interim Dean, CollegeofTechnology

Bowling GreenState University

The most critical changes thatmust bemadefortechnologyeducation to becomeanintegralcomponentofstrategic importance in the total educational enterprise relate to image and teachermainstreaming. Ourimage is notclear, neitherto ourselvesnorto our profession. In discussions lastyear with representatives of ITEA and TfAAP, it becameclearthatwechosethewrong name a few years ago. Why are we always trying to clarify the difference betweentechnologyeducationandeducationaltechnology? Perhapsourname should be technologystudies, parallelingsocialstudies. (Everyoneknowswhat that means.) Then we could further clarify our context and contentunder that umbrella. Of course there would bemuch discussionaboutthesenames. Would it be physical, information, and bio-related technology? Orperhaps, chemical and biological technology? Regardless of the final outcome, I believethatprogressmustbemadeonthe clarification of theimage of our field of study.

Of greaterconcernis the subject of teachermainstreaming. We mustinform our teachers of theirplace in the emergingresearchonthebrain-based approachtolearningandteachingand the delineation ofmultipleintelligences. Many of us canrelate to the difficulties that we experienced as learners in a mathematical/analytical and verbal educational setting. However, when given the opportunity tolearninaspa- 
tial, tactile, musical, kinesthetic, interpersonal, orintrapersonal setting, we excelled. Finally, we are supported by researchrelatingtodominantandmultiintelligence modes. We mustunderstand thisresearch becauseitrelatesto our learning and teaching styles in as significant a fashion as Deweyismsupported ourphilosophy of education.

As the educational enterprise becomes dissatisfied with the limited role that technologyis playing inteaching/ learning, wemustbeprepared todemonstrate how technology can touch everysense, everyintelligence, andevenyreal opportunity to allowlearners to useresources, systems, and processes tounderstand the natural and humanmadeenvironment.

MichaelScott, Associate Professor TechnologyEducation The Ohio State University

\section{Education: AGood BeatButStill Hard To Dance To}

In a chapter in the Symposium II monograph, Bjorkquist and Swanson (1981) used a title similar to the above todescribetheconceptoftechnology education thatthenwasbeingpromoted bymembers of ourprofessionin a transformation from the use of the term industrial arts. While their paper was intended to provoke thought, it is intriguing that the questions theyposed then are just as relevant today. After nearly 20 years (and the development of aconceptual framework, rationale, and structure), why are we still grappling with the concept of technology education?

Those who take a defensive posture claim that the problem is not with technologyeducation but with those who perceivetechnologyeducationasbeing something lesser than real formal education. They claim that we suffer from the Rodney Dangerfield "IDon't GetNo Respect"syndrome.

Whatistechnologyeducation? How must it look in the next century? Our literature is replete with examples of technologyeducationbeing "all things to all people." There are those, for example, who claim that the hallmark of technologyeducationis problemsolving. While problem solving is a desirableoutcomeofanygoodtechnology educationactivity, itis no more unique to technologyeducation than it is to math, science, or any other discipline. Othersfocus upon the integration possibilitiesfortechnologyeducation. They claim that theintegration oftechnology education with subjectssuch as mathematics, science, and/orsocialstudies education is a prescription for survival in the nextcentury and beyond. While several recently developed efforts are showing positive results of the integration with mathematics, science, and technologyeducation, too oftensuch confederations result in big " $M$," big "S," and little "t."

Further, all too oftentoday whenone mentions thetermtechnologyeducation ineducational institutions, the public assumes that we are referring to instructional or educational technology. Clearly, we suffer from a serious identity crisis from the perspective of those outside our profession. In the 1960s, 1970s, and 1980s many of us ran from any thought of being associated with vocationaleducation. While history makessuch phobias clear and sometimesjustified, could it be thatwe haveruntoofarand toofast? Suchother nonvocational school disciplines as mathematics, science, and social scienceshavefoundnewconnectionswith school-to-workinitiatives thatare contributing to a more vital and competitive workforce. By and large, technologyeducationhasbeenasmall playerin thisgameandhassufferedgreatlyforit.

Insummary, technologyeducation professionals need to quit trying to be all things to all people. The field should establishaclearandunique vision. But, more important, we need to clearly communicatewhowearetothose outside of the profession in terms that they understand.Technologyeducationcan and should be a vital part of educational enterprise for the next century.

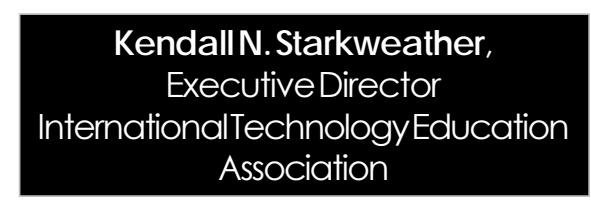

Teacher Shortage. One of the most immediateproblemsfacing ourprofession is teacher shortage. This is a problem not only in our field, but in most areasofeducation.Technologyeducators know of the problem and what caused it. They are now working on solutions for the problem of filling 13,000 vacancies by the year 2001 . It is difficult to geteveryone in our field to understand that the critical shortage of teachers is a problem for all of us. Classroomteachers oftenthink that the problem for universities and many university personnel are not willing put forth the effort required to recruit a sufficientnumberofprospectiveteachers. There aremanyotherperspectives on this issue. The bottom line is that recruitmentof prospectivetechnology educationteachersiseveryone'sproblem. It is a problem that requires considerableattention byeducators atall levels. The challenge will be to get enoughqualified technologyteachers in the workforce to continue to move the profession forward and thus avoid having programseitherclosedorstaffed byunqualified teachers.

ProfessionalDevelopment. The profession is struggling to provide strong leadership across the country. Gone are many university programs of the 1960s that gave teachers a variety of avenuestosatisfying careersin the profession. Gone also are many of the strong philosophicalleaders oradvocates who in days past placed their brands on developments in the field.

A variety of programs needs to be promotedbyuniversitytechnologyeducators whogive direction toinnovative developments. Currently, ITEA is pursuingmanyprofessionalavenuestogive directionandaddstrengthtotheprofession. However, for the profession to be strong, universities throughoutthecountry should be taking the leadership in professionaldevelopmentbypromoting ideas, research, methodologies, andprograms that will guide teachers in their pursuit of excellencein the profession.

Standards Implementation. The ITEA hasled anationwide effort to createa rationale and structure for the study of technology followed by contentstandards for the field. That will be just the beginning of the work. The profession mustnow work on the technologyprograms and courses that will properly teach the identified content of what studentsshouldknowandbeableto do as it pertains to technologicalstudies. Manymodel programsneed to be formulated and tried. Researchneeds to be advanced that will tell us the worth 
of our field to the overall education of students in our country.

Everytechnologyeducatormustbecomeadeveloperofcontentandideas that will further the goals of the field at boththeelementaryandsecondarylevels. Critical segments of our profession are starting to fall into place: (a) rationale and structure for the study of technology and (b) rigorousstandards. The worth of our profession in the years ahead will be tied to how well we will beabletoimplementandmeasure our successes.

Learning Strategies. The way that technology deliversinformation to the classroom has changed the way research will be conducted bystudents. Strongtechnologyeducatorsare using the Internetin theirinstruction in order to obtain and apply the latestinformation available. Teacherswill have to be skilledin designing meaningfulinstruction that utilizes the latestresources in learning how to learn with on-site instruction. The skilled teacher of the future will haveready access to facts andinformation thatwasneverbefore available.Technologyeducatorsmust be leaders in the use of educational technologyandmakefullandeffective use of the electronic world to stay on top of technological developments. Theymustbecomeexpertsinteaching withtechnologyaswellasteachingabout technology.

Program Positioning. Technology education will notapproachits potential until it is considered an indispensable core subject within the school curriculum. If the tradition of keeping technologyeducation underthevocational umbrella as a skills career area is continued,itsacceptanceasalegitimate core subject will always be suspectby felloweducators.

Traditionally, our field has nothada rationale and structure for the study of technologyasacontentarea. Wehave considered ourselves a career exploratory technical skills activity. We must move beyond thatmentality andembrace ourowncontentandmethodology that is evolving. We must position our subject area for its maximum impact on education. For some, this is bold thinking! For others, it is simply the way that the educational system should have been set up in the first place.
SamStem

Professor of TechnologyEducation OregonState University

The mostcritical changes thatmust be made to improve the standing of technologyeducation are those that will clarifyandstrengthencomparative advantage. Asasubjectarea, technologyeducation is part of a competitive marketplace. In averyrealsense, technologyeducation competeswithother subjectsforclass time, spaceandmaterials, teachers, and, mostimportant, students (and their attention). As the educationalmarketplacehasopened up, the relative position of technology educationhasworsened.Whenadministrators, students, and prospective teachers find they have achoice, they rarelychoose technologyeducation.

Considerthechangesbeingmadein my state of Oregon. Like many other states, Oregonhas undertakenanumber of ambitiousinitiativesintended to improve schools. One of these initiativeshasbeenthe developmentofstandards for all subjects, including technology. To earn what is called a "Certificate ofMastery," future Oregonhigh school students will need to demonstrate mastery of these curriculargoals for the area of technology: (a) understand thenature and evolution oftechnology; (b) understand thattechnology canbeusedtosolveproblemsandmeet needs; (c) assess theimpactsand consequencesoftechnology; (d) understand therelationshipsbetweentechnology and otherdisciplines; (e) use a variety of technologicalsystems; (f) demonstrate how technological systems are operatedandcontrolled;and(g)adapttechnological concepts and processes to biological, informational, and physical systems to form technologies andsolve practical problems.

These are indeed worthy goals. But, look at them from the standpoint of comparativeadvantage. Most, ifnotall ofthem,couldbeaccomplishedinother subjectareas.Studentsinsocialstudies classes canlearnmuchabout the nature and evolution of technology or assessimpactsand consequences.l'm confident that students in all classes will learn to use technological systems (primarily computers) fora wide variety of different activities. Music students may very well be involved in demonstrations of how technological systems are operated and controlled. And, it's not much of a stretch to imagine sciencestudents studying how to adapt technologyconceptsandprocessesto biological, informational, and physical systems to solve practical problems.

Technologyeducation has butone distinctareaofcomparativeadvantage, and it is not at all clearin the abovelist. Technologyeducation's comparative advantage lies in providing alearning environment (instruction and facilities) that makes it possible for students to createwithtechnology-tomakethings. The dangerisnot that technologyeducation will go away. Thereal danger is that students will no longer have a place tobecreative withtechnologyaplacetousetechnologytomakewhat canbeimagined.

\section{Leonard F. Stemy, Professor,} GraduateProgram

DirectorforTechnologyand for

Ph.D.Programin Technology Education

University of Wisconsin-Stout

\section{ViableMission}

Ithas beenstated over and overin our literature that we are living in a world that is influenced heavily by a phenomenon called technology. It is alsosaid that the pace of technological developmentwill continue to accelerate and that this will touch the lives of everyone. Therefore, it is argued that everyone must understand this phenomenonifwearegoing to functionas participating citizens of a technologically drivenglobal community.

All of this sounds logical, butwhat is technology and what is our mission? Technologyis the means by whichwe extend capability. Our mission is to developatechnologicallyliterate citizenry: provide persons of all ages opportunities to assess interests, abilities, andopportunities; provide transitioning opportunities that will enable persons tomovesuccessfullybetweenlevels of educationandbetweeneducationand work while continually enhancing the quality of life; and finally, provide an adequatebase forcontinued lifelong learning.

Available to Everyone. Nothingre- 
ally new so far! However, the challengerestsin how we attempt to fulfill this mission. First, we mustunderstand thattechnologyeducationisforeveryone. This includes all students at all levels of education, persons in the workforce, and citizensingeneral. Too oftenweregard technologyeducation as beingjustak-12schoolsubject. And while it is an elementary/secondary schoolsubject, the K-12system of educationmustprovideadevelopmentally appropriatesetofexperiencesthatconsiderallstudentsregardless ofage, gender, ability, learning style, interest, or choice of postsecondarypursuit.More specifically, thismeans programs must attractthefemalepopulation, challenge the college bound, and domore than just keep disinterested kids busy and out of the principal's office. Technology is not just a male thing. It is extremely sophisticated and, therefore, potentiallychallenging toeventhemost academicallyable. And asforkeeping kids busy, we can do even more by providingrealisticexperiencesthathelp to develop skills for application outside ofschool. In addition, thestudy of technology is equally appropriate for college and university students and persons in the workforce. Postsecondary studentsneed tostudy technologyasa part of their general education to be broadlyeducated. Workersneeditto betterunderstand their organizations and toidentifycareerand training pathways that lead to advancements and careermobility.

Must Have a Body of Knowledge. Although it is an evolving field of study, technologyeducationneeds toestablish ascholarlybody of knowledgethat depicts technology. In the past, these effortshavesometimesbeenemotionally charged and political. Emotional in asense that those willing to take time to provideleadership often determined the direction of the field. And I might add, this was positive in that at least someone tried to move the profession forwardandintonewand exciting possibilities. Asforbeing political, the question was too often asked, What will the field accept? rather than What is the rightstuff to teach ourchildren to best positionthemforlife in the 21stcentury?

Technology is technology. It has common characteristics that are universal; and we, the profession, must determinethose attributes and design programs of study to deliver the right content. While consensusisimportant, scholarship is essential.Standards are currentlybeing developed byindividual states, at thenationallevel, andincountries outside the United States. I have highhopeforthestandards and thisrare opportunity to make asignificantcontribution to finding the right content for thestudy oftechnology.

MustBe Positioned. Much of what I havejustsaidhas beensaid before.The challengerests with doing it. Although someimprovementshavebeenmade, theyarespotty. Considerable program differences can be found fromone districttoanotherandbetweenstates. As a result, we demonstrate different and inconsistentexamples of technology education. It is nowonder that we are oftenmisunderstood. We send mixed messages to ourconstituencies. We oftenwriteandspeakonething,butdemonstrate something that is quite different.Weneedtokeepwritingandspeaking the rightstuff, butmore important, we need to demonstrate it in classroomsandlaboratoriestoparents, counselors, administrators, colleagues, legislators, highereducation, and business andindustry.

Earlier I said we need to identify content thatisrepresentative of technology, and we must. As a profession, weadvocateworkingmoreclosely with mathematicsandscience. However, if this is true, then we also must position ourselvesmore like mathematics and science. These fields ofstudy are delineatedbyprofessional communitiesand influenced less by the interest of a teacher, principal, or local board of education. Yet, we are willing to let everyschool determine its own technology curriculum. While, in part, this is good, for the most part it is notgood becauseitleads to this appearance of disarray. For purposes of study, technology is anything anyone wants it to be. Wemustovercomethistendency. Technologyis something that can be structured forstudy. If we want to bea viable part of every school's curriculum, we have got to clearly demonstrate itinevery classroom and laboratory. Action in the classroom speaks more loudly than our articles, curriculumguides, andspeeches, asimportant as theyare.

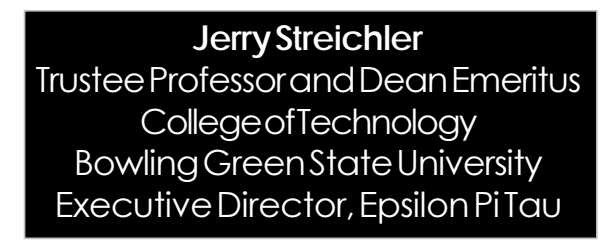

Perhaps when recognition is achieved as a most wise elder of the profession, one can gamble. Indeed, RayKarneshas takenagamblebyproviding an opportunity for a group of us to pontificate. Buthe did put a leash (Should lsaymuzzle?) onusbyallotting verylittle space in which to make our statements. Sol have tried to meethis challenge by firstraising one caution or concem, undertheheading ofParanoia (?), thatmayberelated to whatmustbe done. I follow this with a comment under The Nobel Prize in Technology: Delusion of Grandeur (?). It is a vision that poses the challenge of what we ought to strive to realize in order to be a trulyintegral and effective component of the totaleducationalenterprise.

Paranoia (?). Itwould be difficult to fault the InternationalTechnologyEducation Association (ITEA) strategy and itsaccomplishmentsinthe pastseveral years. In fact, on re-reading Karnes' 1960 statement "Improve or Perish," it seems that we are only now realizing his prescient comments through the ITEA work. But even Karnes may not have foreseen the links with NASA, NSF, and the engineering community thathavebeenachievedalong with the formation ofthejust-announcedCenter to Advance Teaching ofTechnology \& Science (TfAAP, 1998). The former organizations are involved with ITEA's Technology for All Americans Project. Thenewcenterdoeshave "science" in its title, and while its purpose is to "...ensure the education of technologically literate citizens," there is no mention of an endeavor to help educate citizens to be scientificallyliterate. Elsewhere in the description, reference is made to an interest to "enhance the teaching oftechnologyandsciencein school classrooms, "butmy reading of thestatementleaves me with theimpression that the focus of CATTS is to promotetechnologicalliteracy.

Room does notpermitacomplete presentation and analysis of matters, events, anddevelopmentsthataresomewhat connected with the preceding. 
But a provocative list includes: 1) funded projects for curriculum developmentinmathematics,science, and technology; 2) the Science, Technology, and Societymovement; 3) Tech prep; and 4) the high school program Engineering Principles. Alsorelated are NationalScience Foundation policies and actions such as: (a) the use of the termadvanced technologicaleducation by some NSF directorates to describe whathas been widely known as technical workforcepreparation offerings at the community and technical college level, and (b) the use, in virtually all NSF presentations and publicity materials, of the term scientific and technologicalliteracywheresomeyears ago the word technologywas rarely, if ever, linked or included as they currentlyare doing.

Does this mean that we have arrived? Or could it mean that we have taught our lessons so well that those with greaterinfluence and who are in the established disciplines and corridors ofpowercanrun with the wonderfuldoctrines that ourprofession had for solong turnedinto practice? Thewonders accomplished by ITEA notwithstanding, and the extraordinarysuccesses of recentyears not diminished, we ought to carefully take the time to envision the scenarios thatmayunfold which may either result in the profession being truly established and acceptedorseeothers deliveringourcarefully honed and visionary practices in theschools.

The Nobel Prize in Technology:DeIusionofGrandeur(?).Letmerevealmy position right off. It is that if we are talking about a profession that will be able to holdits own among the established disciplines, then we need torealize that the accomplishments of the ITEA have only to do with what is a part of the profession thatought to beconceivedandbuilt.Shouldwesucceedin doing that, thenone daythatprofession will produce a person who will win the Nobel Prize in Technology that the Swedish Academy will establish. Inher orhis acceptancespeechinSweden, the winnerwill look back at whatcontributed to becoming the person who could win the prize and would talk about: (a) becoming excited during the earlyyears of schooling abouttechnology as a human endeavor thatholds greatpromise, challenge, and sometimes threat to the world'sinhabitants; (b) technologylearningexperiencesthat expandedcreative-thinking and problem-solving abilities and that provided a firm foundation to become anindependent learner which served well throughoutlife and career; (c) teachers of technology at all levels, who while theyhadahigh degreeofknowledgeof technology subject matter as well as mastery of learning and instruction, functioned as totally effective facilitators and thus contributed to thestudent becominganeffectiveindependentand lifelonglearner; (d) arecognized technologysequence in the schools that branchedoffintoworkforceand career preparationofferingsatappropriatelevelsandtheunderstanding,respect,communications, and mutual support that existedbetweenandamong teachers, faculty, and administrators of all these programs thatwas clearly projected to students, parents, and the citizens of the widercommunity; (e) the extraordinary teaching andresearch and contributions of university technology faculty that embraced the general consequences of technologyin society, the society of the futureasaffectedbytechnology, and specific areas of concern thatdrewuponthespecializedcomponents of technologysuch as engineering, industrial technology, design, biotechnology, technologyassessment, and teaching and learning in technology with all involved enjoying a sense of equality, mutualrespect, andsupport; (f) the fascination that those involvedin preparingtechnologyteachersforthe publicschools, unlike the case in other disciplineswhereteacherpreparation facultyonlypossessedashallowpreparation in theirsubjectmatter discipline that theytaught, werecapableproductive scholars, not only of the art and science of teaching and learning, but capable, in theirownright, inengaging inhighly complextechnologyresearch requiring sophisticated knowledge of thescience, mathematics, and engineeringrelevant to the project; (g) the enormously effective work of the umbrella organization, The International Association for the Advancement of Technology, to which organizations such as ITEA, NAIT, NASTS, ASEE, ATEA, divisions of AVA, and counterparts in other countries belong, and which is credited with exerting significant influence in establishing and strengthening technology as an academic field andits acceptanceinsociety; and (h) howbydropping the confusing term technologyeducation in favor of simply using technology, the leaders contributed significantly to founding the profession that includes elements thatare describedin the preceding bitemsandwhich characterize the profession that produced the speaker, the winner of the Nobel Prize inTechnology.

\section{References}

Karnes, M. R. (1960). Improve of perish. Washington, DC: The American Industrial Arts Association.

TfAAP. (1998). Standpoint. Blacksburg, VA: TechnologyforAllAmericansProject, p.2.

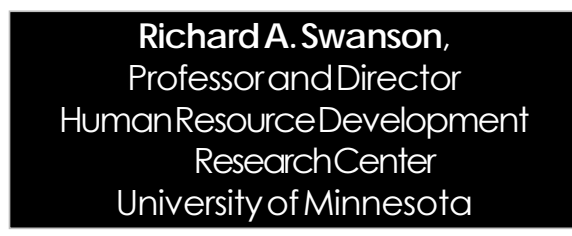

\section{It'sthe Theory, Stupid}

In arecentpresidentialelectionwe heard the refrain-"It's the economy, stupid!" Beyond the knee-jerkreaction to the use of the wordstupid, the motto was a blunt message as to the importance of theeconomy versusthesmaller issues being debated. It served as a splash of cold water in the faces of everybody. The following comments areintendedtohavethesameeffecton ourtopic.

The thesis here is that technology educationmustmake significantscholarlyadvancesinestablishing the theoretical and disciplinary foundation of technology in order for it to realize its potential. Withoutasound technology theory and disciplinary focus that is recognized by those in and out of the profession, technologyeducation will notbe taken seriously by society orby the educationalenterprisesitsupports.

A theory simply explains what a phenomenon is and how it works (Torraco, 1997, p. 1 15), while "a discipline is a body of knowledge with its own organizing concepts, codified knowledge,epistemologicalapproach, undergirding theories, particularmethodologies, and technical jargon" 
(Passmore, 1997, p. 201). The idea is widely held that technologyis a discipline that draws upon many theories. This overlygenerousideahasserved as fools' gold to the profession. In the attempt to be inclusive of so many theories - stakingits claimso broadlyit has come up with no theory.

Modelsoftechnologyeducationhave been developed and disseminated through books, seminars, and consulting projects that are little more than diagrams based on the author's most recent consulting or curriculum developmentexperience.Armedwithatechnologyconceptdiagramandadescription ofitscomponents, technologyeducationprofessionalsmarchinto theeducationalarenahopingtoaffectchange. Whilethetechnologyeducationmodel may be powerful enough to guide change in that situation-primarily throughthepersistence of theleaderit is most likely too superficial to explain the complex dynamics of technologyitselforbe broadlyaccepted.

Youcanhaveamodelandnotheory, you can have a theory with nomodel, andyou can have a theoryaccompanied byasupportingmodel. Thiscanbe said oftechnologyandtechnologyeducation. Furthermore, espoused theories are not theories. Espoused theories are mostlynarrative versions ofmodels and donotpass the scholar's test of whata theory or discipline is. Theory-building researchishardworkandneedstobedone.

In short, a model derived from logic is no substitute forsound theorybased ontheory-buildingresearch thatestablishes the discipline of technology. Full andresearch-basedmodelsoftechnologytheorycanguideimprovementeffortsthroughvalidatedrelationshipsand the ability to test those relationships. Once established, the work of bounding technologyeducation will berelativelyeasy.

Tim L Wenting Grayce Wicall GauthierProfessor of Education \&Head, Human Resource EducationDepartmentUniversity of llinois atUrbana-Champaign

Thechallengethatemergesfrom the questionposedbymy colleagueM.Ray Karnes is not a minor one. We are in a constant state of change, and as they say, ifyou are notchanging, everyone is
passingyouby.Technologyeducation is notexemptfrom this phenomenon.

The argumentsfortechnologyeducation are obvious to all of us who are connected to the profession. The ones thatstand the highestin myestimation are related to orientation to a technological society, learning problem-solving skills, learning teamwork and other work-related skills, and learning the nature of technological change (if not changeingeneral). We all knowhow fasttechnologyisemergingand changing. New microchips every 12 weeks, newandimproved(andcheaper)computers every three months, and so on. Theschoolis a place where our citizens of the futurelearnhow to deal withnew technologyand how to embrace the technology for theirbenefit. However, still having young children, I see students doing the samethings they have alwaysdone:reading, listeningtobroadcasts from teachers, doing worksheets and written assignments, and the other normal things kids have done for the lastcentury.

The computer, they have said, will change the way our children will learn. But, since the development of the personal computer in 1981, little has changed in the way students learn. Matter offact, mostcontemporaryadvancesinlearningstrategies (emerging from the work of cognitive scientists) are related to teacher-ledstrategies in the classroom. Interestingly, many of these "new" strategieshavebeeninuse bytechnologyeducatorsfordecades.

If Tapscott is right in his prognosis in his book Growing Up Digital, the currentand future generation will be very differentin the way theyplay, socialize, learn, andwork. Technologyeducators can be leaders in this evolution by providing guidance to children and adultsinlearning adaptivestrategiesfor this new era. For this to happen, I believe technologyeducation mustbecomeanintegral part of the cumiculum. Recentconcepts of stranding content maybeonewave.Anothermightbethe arteducationmodelwhereartteachers move around school buildings from classroomtoclassroom. Itmightbethat there is no such thing as a technology teacher. Maybe all teachers need to teachtechnology.

The problem, of course, with some of thesenotionsis thatwemaybeafraid toleadsuchachargebecausewemay end our discipline as we know it. We might lose our identity, have no proteges, gooutofstyle. Ourchallenge is to think "outside the box" and to think aboutwhat thenextgenerationneeds andhowtheirneedsmightbemetwhile setting aside our selfish interests. When wecandothat,wecanleadtechnology educationintothe 21 st century.

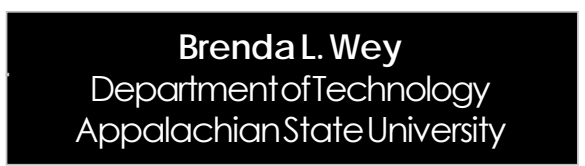

Technologyeducation is a holistic body of knowedge and experiences, and touches every aspect of the individual and oursociety. Understanding and applying technological principles is intrinsic to our future success as a countryina dynamic worldeconomy. Butacheiving thisis complexandever changingand haspresentedaconstant challengeforthetechnologyeducation teacherand educator. As the knowledge base changes, we must also change, and changeisnotalwayseasy. The profession is confronted with many questions: Whatshouldweteach? What is ourcommonbodyofknowledgethat defines our discipline? What are the besttechniques for delivering the information? How canwecommunicate, to thoseinsideandoutsideourprofession, the importanceofthisknowledgeasanessentialelementofbasiceducationforallstudents? Howcanwedevelopavisionthat will carry usintothe 21stcentury?

This week we had the pleasure of having James Burke as a guestlecturer on our campus. His presentation was advertised as being abouthowsociety should prepare for a future with the Internet. But the actual presentation topic, the Internet, onlybrieflysurfaced a couple of times. The importance of innovative thought, nonlinearthinking, was whathe talked about. Burke presented a web of seemingly unrelated artifactconnections thatreflected the importanceandrealityoftechnology:a clearvisionfortechnology.

As aprofession we maylearnsomething from the connections that James Burke has made for society and technology. Weneed tolink these connections in the web of new technology to be created and used in the future. As technology teacherswe need to pro- 
vide the foundation for innovative thoughtandanunderstanding oftechnological processes and theirimpact on society. Technology is a body of knowledge essential to oursuccessin the nextcentury. Unless ourprofession cancome to a clearunderstanding of ourvision andfuturegoals, how canwe clearly communicate and share ourvision with others?

\section{Tom Wight George \&}

Frances Ball Distinguished Professor

of Industry \& Technology

BallState University

\section{Defining Technology:A PrerequisitetoAcceptance}

The first and most critical step in becomingaccepted as a coresubject is to develop a clear vision of whowe are, whowe are not, and what we are about. Thisinvolvesembracing theidea that technology is a discipline of knowledge. It meets the criteria presentedbyKing and Brownellin their book, The Curriculum and the Disciplines of Knowledge.Technology is a community ofscholars who share a domain of inquiry or discourse and a concernforefficientand appropriate actionusingtoolsandmaterialstocreate human-made systems and structures. Technologyisaninstructive community that includesinformation that is useful to people. Ithas a tradition: a history of events, discoveries, and personalities. Technologyhasitsownmode ofinquiry: acreative process to gain newinsight thatwe callinventionandinnovation. It has its own language: a unique vocabularyandwayofcommunicating ideas (engineering and architectural drawing).Technologyhasitsowndomain: abodyofaccumulatedknowledgeabout practice with tools, materials, and engineeredsystems.Andtechnologyisan expressionofhumanimagination;itisnot discoveredbutitiscreated.

Karenzuga, Associate Professor of TechnologyEducation The Ohio State University

It has been almost 40 years since RayKarneschallenged the profession to improve orperish, and technology education and educators continueon a downward slide to oblivion in the
United States. We havereorganized our deck chairs as curriculum at least onceandweareembarkingonanother attemptto dosothrough thenewstandards, and the ship is still sinking. While many of ourinternational counterparts are experiencing eithernew or resurgentinterestandgrowthintechnology education, technologyeducationefforts in all types of schools in the United States continue to decline. How could thisbehappening tosuchanimportant idea, teaching abouttechnologyinan increasinglytechnological world? Idon't believe it is the idea, I believe it is us, collectively, because we still view the problem myopically. We continue to lookinwardly, atourselves, wondering what is wrong, if we aren't dressed appropriatelyfordinneratthecaptain's table, and what we need to do for ourselves in order to secure our future. We are not taking a stand on the concerns andissuesfacing allstudents and educators;instead, westandinthebackground worrying aboutourselves.

Afterall these years, we have yet to demonstrate totheaveragecitizenand totheeducationalcommunitythattechnology education is of value in the generalefforttoeducateall children.In this country, educational value for all is still placedupon the academics, while experiential education, such as technologyeducation, is viewed as "frills." Thebattletosecureaplacefortechnologyeducation is the battle that other subjectmattereducators havehadin ourschoolswithrespecttogaining acceptanceforactivity-basedteachingand instruction. The terms have changed over the years, education as experience, hands-on, problemsolving, contextuallearning constructivism, situated learning - they all point to the realization on the part of someeducators that teaching childrenthroughproblemsand activities is effective. Other than parroting the mantra of problemsolving, technologyeducatorshave done little to join with our colleagues in mathematics,science, andotherschool subjects in order to bring this goal and their ability to contribute to achieving it totheattention of theeducationalcommunity, muchless the general public.

Wehave little tonoevidence of the value of teaching all childreninlaboratorysettingsabouttechnologyand the relationship thatmayhavein teaching childrento beliterate, successful, innovative, and self-renewing adults in our society. Welack the research andresearchers who could helpus. Based upon historical practice in technology education, welack thepopulationbase of having all children in our classes, and, therefore, we have alack of support from the entire population base of the country. We simply lack a world view that sees us as a part of the whole effort, and thisleadsus tomyopic activity, such as curriculum reorganization, asweignore both theicebergslurking in the treacherous waters in which we choose tosail and the potential partners with whom we could sail as we strive to improveeducationforallstudents.

\section{CONCWDING STATEMENT}

Several contributors elected tolimit theresponse to one ortwo problemsor issues while others preferred to covera wide range. A few concentrated on such singularsolutions as anaggressive and sustained public information program, the definition of technologyeducationanditsrolein the education ofall students, leadershipdevelopment, and the major problem of preparing large numbers of highly qualified teachers and other professionals in the field of technologyeducation.Severallentsupport to the Technology for All AmericansProjectandexpressedhighhopes for the positive influence the acceptance of carefully-formulatedstandards and the impact theirimplementation will undoubtedly have on technology educationintheyearsahead. Thecontributors also expressed confidence in the International TechnologyEducation Association anditsmanyalliances with otherinfluential organizations and agencies. Theshortchangeafforded the American Vocational AssociationStreichler and Dyrenfurth notable exceptions-came as a surprise to me aftermorethan 40 years ofinvolvement in both the ITEA and the AVA and in the latter's trade and industrial, industrial arts, and technicaleducation divisions.

The following are the only changes of any consequencemade in the precedingsections of thispaperafteritwas presented at the 85th Conference: a paragraphdeletedandoneaddedtothe introduction, and the addition of two 
statements thatwere submittedinresponse to an invitation extended after the conference convened. From this point forward, however, major revisionshavebeenmadeasintendedfrom theoutset.

Thirty-five respondents leftall of us deeplyindebted toeach of themwhen theysubmittedstatementsforinclusion in this paper. Twelve of the authors attended the 85th Mississippi Valley Technology TeacherEducation Conference and participated in the lively discussions thatfollowed the presentation of papers: Custer, Dugger, Erekson, Evans, Herschbach, Householder, Martin, Pucel,Savage,Scott, Streichler, and Zuga. Before making a few observationsabout the piecessubmitted bythe contributors, let me report with pleasure that theotherparticipants treated each of the 12 in attendance withrespect.

This projecthas afforded me a delightful opportunity to review the numerousand variedresponsessubmitted under rather severe time and space restraintstoacompellingquestionabout changesurgentlyneededintechnology education.Readingtheprecedingstatements turned out to be a thrilling and exciting experience, made me immenselyproud tobeassociatedagain with formerstudents and colleagues, and the pessimismexpressed by afew of the respondents notwithstanding, generatedhighhopesandgreatexpectationsas the future of technologyeducationis envisioned.

Space limitations permitbriefreferences to only a few of the statements submitted and to a limited number of the problems and issues raised in responses to the question posed. The omission of the name of a specific authorinthefollowing observationsshould innoway detractfrom theimportance of that author's contribution.

Letrespondents whobemoan the fact that technologyeducation is getting short shrift in the struggle for a position in the sun be reminded that math, science, and foreignlanguage teachershavebeenregistering asimilar complaint for ages and are likely to enter the coming century bearing the same cross. To those who press for massive and continuous public information campaignsandaggressive political action: Go get 'em, Tiger! But before the first shot is fired, make sure that the program being promoted is worthy of your unqualified support. While several of the respondents presented excellent suggestions for promoting public awareness of the relevanceandimportance oftechnology education programs of high quality in the school, the points made by Herschbachshouldbeafforded careful consideration as continuing publicinformation campaigns are planned. If applied with somewhatmoresubtlety thansuggestedbytheirforcefulpresentation, thepointsmadebySanderscould becomeimportantindeveloping publicawareness.

To the few who seem to favor the preservation of the historical chasm betweentechnologyeducation and vocationaleducationthathasbeencultivated all too long and far too aggressively by reactionaries on both sides of the fence, letmesuggest thatyou as a group may be destined for a fall in the crevasse. Where is your logic when in the same breath you press for close alliancesborderingonintegration with generic forms of vocationaleducation commonlyknownasmathematics, the sciences, and other academic disciplines, such as engineering, law, medicine, architecture, business administration, etc. Letme directattention of all inclined tokeeparespectabledistance betweentechnologyeducation and vocationaleducationtotheentirestatementsubmitted by Dave Bjorquist. My position on this issue is currently and always has been in harmony with the onepresentedeloquentlybyhim—and reinforced by Pucel, Ray, and, especially, Moss - in the following excerpt from his contribution to this paper:

Asvocational educationredefines itself, vocational curricula are becoming less specialized. At the same time the academic subjects are becoming moreconcemedaboutpractical applications beyond schooling. The time is propitious to exploit, rather than resist, thenaturalconnectionsbetweentechnologyeducationand the worldofwork. The occupational implications oftechnologiesandtechnologicalchangeprovidearichresourceforexploring awide variety of careers. Technologyeducation teachers should deliberatelyplan and provide for a widerange of experi- ences thathelp students learn about themselvesinrelationtorelevantoccupations. And the planning should be done cooperatively with vocational teacherssothattheoverallcareerdevelopmentofstudentscanbeaccomplished as efficiently as possible.

If technologyeducationistohavean importantrolein the total educational enterprise of the coming century, we muststrive continually to establish and maintain close and appropriaterelationships with the rest of education, especially those phases committed primarily to preparation for the world of workand careeradvancement. Thereis goodreasontoassumethattechnology educators all over the world will be encouraged by the promise and probable impact of two current developments of technology education programs of the future: the Technologyfor All Americans Project under the auspices of ITEA and ourassociation'sclose andamiableworking relationships with several very powerful and influential associations and agencies. You will surely want to join with the several contributors who expressed highhopes for these developments. For an excellentoverview of the work of ITEA, refer totheexecutive director'spaperandhis list for further readings in the previous issue of this journal (Starkweather, pp. 44-47).

Sharon Brusic and Stephen Petrina elected tostressaproblemthatisapparently farmore critical today than any of us could have anticipated at the time thefollowingfacetiousobservationwas madenearly 40 years ago: "When the problemofevolvingadaptationsnecessary to meet the needs of girls and women in [technologyeducation] is studied rigorously, a very simple solution will become apparent. Two sets of toiletfacilities will be provided near the shop in the place of the usual one markedboys" (Karnes, 1960). Thatstatementsprang fromhigh hopesthatlong agotechnologyeducation would have evolved to the point that neither Brusic nor anyone else would be issuing her current challenge to the profession: "Despitesomeattemptsinthepastdecadetobroadentheappealoftechnologyeducation to both males and females, there is still an incredible gap in female representation in technology 
education at all levels." Petrina also madesomeinteresting observations about the maleness factor that is in effectclosingthetechnologyeducation door to half the population! Do join with the Brusics and Petrinas of their respective countries and promotevigorously the attitudinal change that will openthatdoorquickly!

Incidentally, you may wish to refer again to Petrina's entire contribution, and this time look for all of the challengesembeddedtherein.

Please note thatPaulDeVore and RupertEvanselectedtogobeyondexistingeducationalinstitutionsandagenciesin formulating their responses to the question and issuing bold challenges to the profession. If a firstreading leavesyou inclined toreject their proposals as being impractical, do give them furthernotice. Many of the most powerfulinfluencesontheschoolhave come from beyond the walls of the schoolhouse. A casual stroll through the exhibit hall at one of our recent nationalconferencesleavesonewith theimpression that the types of instructional modules to which Rupertrefers areattractingattention.Paulsurelyfeels thatalegislative mandate to ensurea place fortechnologyeducation in the schoolis neither desirable nor feasible. However, if "linked together with the privatesector" ashesuggested, there could be real merit to his call for a "...freeandindependent, dedicated national academy or center of high quality... and regional centers [that] wouldreplaceantiquatedteachereducationprograms."

Many other respondents joined DeVore and Evansin directing attention to the alarming state of affairs in technologyteachereducation, andseveralsuggested that this is the most criticalproblem confronting the profession. I have elected to address directlyonly thatonecompelling problemandsuggest a solution somewhat less drastic than the one with whichDeVore challengesus. Before doingso, however, let mesuggestsome of the essential qualifications and the attributes of the technologyteacherof the coming century by referring to my favorite technology teacher of the past. (While the individualdescribedhappenedtohavebeen aman, my hopeis thatin thenearfuture there will be a 51-49 chance that the mastertechnologyteacherof thenew day will be alady!)

Myfavoritetechnologyteacherhad thetemperamentand the understanding towork amiably and cooperatively withstudents across a broad age and aptituderange. Hehadbeen abrilliant student and had learned very well indeed from his associates and fromone particularmentor. He tookfulladvantage of the mostsophisticatedinformation retrieval systems of his day tokeep abreast of abroadrange of technical knowledge applicable to his profession. Heacquiredandemployed dailya wide range of skills and mastery over materials, tools, and other devices that earnedhimrecognition as the ultimate mastercraftsmaninhisfieldofendeavor.

Thelaboratoryin which he enjoyed every day of his long and illustrious careerwas thatofanexplorer, inventor, orinnovator. Itwas in this environment thatthismastertechnologyteacherdesigned and producedinstrumentsadjudged universally to be the all-time, best-of-class in function, form, style, aesthetic value, andresonantresponse to the will and artistry of all accomplishedperformersfortunateenoughto possess one. It was in this laboratory environment that Antonio Stradivari (1644-1737) applied what he had learned from his remarkable mentor, Nicolo' Amati, and manyotherassociates, and from his own continuing series of explorations and experiments as he initiated the Stradivarius tradition and validated the exceptionally high standards to which his pupils (apprentices, including several of his 11 sons) responded as they extended their mentor'sinfluence on a noble professionandperpetuatedhisdynasty.

Myfirmconvictionis thateverytechnology teacher of this day and tomorrow should be able to hold and make advancementinademandingposition as a technician in the private sector, as did Antonio Stradivari in his time, and that this capabilityshould be validated and confirmed byatleast two years of full-time employment for pay in his or hertechnicalspecialty.

Back to the urgent problem of preparing the highly skilled and technicallycompetent counterparts of Antonio Stradivari in sufficient number to stafftheevolvingtechnologyeducation laboratories of the coming century.First,
I wouldrejoice as acurrent trendacceleratesandthenextendcondolencesto the remaining small, woefully weak andinadequate technology teacher education programs and the antique shopsinwhich theybecameobsolete andthenperishedmanyyearsago.Shut down the fewremaining on the campuses of our most prestigious universitiesknownforadvancedstudyandresearch. Ignore the formerindustrial arts teachereducation programsinmany otherinstitutions thatwere presumably converted to programs for training the technicians but never staffed and equippedtomeetacceptablestandards. Nowletus turn to the fewinstitutions in whichtechnologyteachereducation might possibly find a good home and enjoyadequatesupport.

While this is neither the time nor the place to favorspecificinstitutions, each ofus probably knowsintimately two or three of the very few vibrant colleges and universities in which a thousand, twothousand, ormorestudents ofhigh potential are currentlyreceiving excellent preparation for careers as technicians on a single campus in very rigorousand comprehensivetwo-, three-, or four-yearprograms. Millionshavebeen appropriated to each of these institutionstoprovideadequatespace,stateof-the-art laboratory facilities and instructional resources, and to employ dozens of highly qualified faculty and staffmembers.

There are several institutions in this class in which a strong and dynamic professionalteachereducationcomponent is already in place and in which there is a clearly established record of adequate appropriations and other forms of tangiblesupport to keep quality technicalprograms currentandadd new onesinresponse to accelerating technologicalchange. Itisintheseparticularinstitutions that the technology teacher of the future can bestbe prepared fora distinguished career.

A critical question: How can we recruit, in sufficient numbers on any onecampustosatisfythecost/efficiency criterion, themostcapablestudentswho complete formal preparation for careers as technicians to continue in a programleadingtotheteachingprofession? Please recall again that many of thecontributorsexpressedapprovaland highhopesas theyreferred to the good 
workbeing performed by the ITEA and to its close alliances with several influential associations and agencies. Thisis the time and place to test the spine of the ITEA, the associations and agencies with which amiable working relationships have evolved, and the will of the members of Epsilon PiTau. Mymodest proposal-in part a response to the critical question raised forcefully by Dyrenfurth and several othercontributors - is that the ITEA and the AVA, in partnership with theirrespective and, insome cases, joint allies, seekfederal legislation that provides for the following on a long-term basis:

- Funding for atleas 3,000 annual, full-tuition fellowships that may be allocated, inresponse to application, in blocks of notless than 100 to each of a limitednumber of colleges and university institutions and then awarded to graduate technicianswhoseekfurther preparation for careers as teachersin the field oftechnologyeducation.

- Allocation of fellowships to be limited to institutions in which there is a clear record of strong support for teachereducationand forawiderange of programsin whichlarge numbers of outstandingstudents are receiving excellentpreparationforcareersastechnicians.

- Granting of fellowships to be limited to graduates of two-, three-, orfouryeartechnical programscomparableto those offered by the class of institutions mentionedaboveandhavehadatleast twoyears ofworkexperienceasatechnician or will pursue a technology teachereducationprogramthatincludes employmentinatechnical pursuitasan integral componentunderacooperative arrangement with the privatesector.Each fellowshiprecipient to teach notfewerthan two yearsforeachyear the fellowshipis accepted.

The National DefenseEducationAct of 1958 and the subsequentelementary, secondary, and highereducation actsunderwhich federal dollars by the billionswere appropriated for education prior to 1970setprecedents for this modestproposal.Iwasright therewhen many ofyou whohaveachievedprominenceintechnologyeducationcompleted youradvanced degrees while notonly holding fellowships awarded during the post-Sputnik era but also drawingstudentand dependentsupportstipends provided by the NDEA or subsequent acts. The institutions you attendedalsoreceivedfederalfundsin proportion to the number offellowship recipients on campus. These student and institutional support provisions shouldalsobeincluded whentheworking copy of the bill is prepared for the TechnologyTeacherEducation Actof 1999 !

Yourstudents and theirparents, your fellowteachersandotheremployeesin your school system, board members, and citizens of the community at large will be the primary advocates foryour program and will ensure its prominent rolein the educationalenterprise of the newcenturyifyourprogramis dynamic and in its response as scientific and technologicaladvancementsaremade andascomplexities of thehumanexperience increase, and if your program affords students a wide range of challenging and stimulating opportunities for the application of the many disciplines of theschoolas theyidentify and define problems, raise questions, explore, innovate, assimilate, experiment, invent, design, create, perform, build, automate, interpolate, project, extrapolate, predict, validate, produce, relate, infer, integrate, interrelate, cooperate, maintain andrepair, adapt, renovate, adjustand control, and developawide range of finely tuned skills in a vibrant laboratoryenvironmentrichlysupplied withstate-of-the-artmaterials, informationaccessresources, tools, machines and testing equipment-all of this orchestrated by a skilled, masterful, and inspiring teacherwhorecognizesno limits!

And now you know why, from my own historical perspective and with high hopesfor the coming century and with unbridled confidenceandboundless enthusiasm, it is such a great pleasure forme tojoin wholeheartedly with PaulDeVore (1998) as he punctuated his scholarly and challenging piece in the preceding issue of thisjournal with the following delightfully optimistic refrain: "I said I want to start over. And you ask why? And Ireply, because the present is so exciting and the future holds such great potential. Each of us hasopportunitiestodaythatarebeyond even those we envisioned in our wildest dreams when we first began our careers" (p.2).

\section{References}

DeVore, P. W. (1998). Reflections of technology in the past, present and future. The Journal of Technology Studies, 24(2), 2-7.

Gallagher, J.V. (1993). Improve or perish revisited. The Technology Teacher, $52(4), 28-32$.

Hill, W. H., Hill, A. F., \& Hill, A. E. (1963). Antonio Stradivari: His life and work (1664-1737). New York: Dover Publications.

International Technology Education Association. (1996). Technologyforall Americans: Arationale andstructure for the study of technology. Reston, VA: Author.

International Technology Education Association. (1998). Standards for technologyeducation. Reston, VA: Author.

Karnes, M. R. (1960). Improve or perish. Washington, DC: The American Industrial Arts Association.

Starkweather, K. N. (1998). The International Technology Education Association (ITEA): A prominent voice fortechnologyeducation. The Journal of Technology Studies, 24(2), 44-47.
Copies of thisSpecial Sectionmaybeorderedinthe following quantities and prices:

- package of $15 @$ US $\$ 30.00$

• package of30@ US\$55.00
Send purchase ordersto: Epsilon PiTau, International Office College of Technology Bowling Green State University Bowling Green, OH 43403-0035 